\title{
Larval ecology and infestation indices of two major arbovirus vectors, Aedes aegypti and Aedes albopictus (Diptera: Culicidae), in Brazzaville, the capital city of the Republic of the Congo
}

Theodel A. Wilson-Bahun ${ }^{1,2+}$, Basile Kamgang ${ }^{1 *+} \mathbb{0}$, Arsène Lenga ${ }^{2}$ and Charles S. Wondji ${ }^{1,3}$

\begin{abstract}
Background: Invasive mosquito species, such as Aedes albopictus in Congo can affect the distribution of native species, changing the vector composition and pattern of disease transmission. Here, we comparatively establish the geographical distribution and larval habitat preference of Ae. aegypti and Ae. albopictus and the risk of arbovirus disease outbreaks using Stegomyia indices in the city of Brazzaville, the capital of the Republic of the Congo.
\end{abstract}

Methods: Human dwelling surveys of water-holding containers for immature stages of Aedes was carried out in December 2017 in Brazzaville through a random cluster sampling method. A total of 268 human dwellings distributed in 9 boroughs and 27 neighbourhoods were surveyed across the city.

Results: Overall, 455 potential larval habitats were surveyed. Both Ae. aegypti and Ae. albopictus were collected across the city with an overall high prevalence of Ae. aegypti (53.1\%) compared to Ae. albopictus (46.9\%). Geographical distribution analysis showed that Ae. aegypti was more abundant (mean $=6.6 \pm 1.4$ ) in neighbourhoods located in downtown, while the abundance of Ae. albopictus was low (mean $=3.5 \pm 0.6$ ) in suburbs. Peridomestic containers, especially discarded tanks, were the most strongly colonized productive larval habitat for both mosquito species with the prevalence of 56.4\% and 53.1\% for Ae. aegypti and Ae. albopictus, respectively. Globally, the house index (HI), Breteau index (BI) and container index (CI) were high for Ae. aegypti (26.6\%, 38.4\% and 22.6\%) and Ae. albopictus (33.3\%, 49.6\% and $26.6 \%)$ compared to the transmission risk threshold (5\%,5\% and 20\%) established by the WHO/PAHO. Overall, pupae-based indices (the pupae index and the pupae per person index) were not significantly different between Ae. aegypti (273.4\% and $23.2 \%$ ) and Ae. albopictus (228.8\% and $19.5 \%)$.

Conclusions: The findings of this study suggest a high risk for transmission of arbovirus diseases in Brazzaville and call for an urgent need to implement vector control strategies against these vectors in the Republic of the Congo.

Keywords: Aedes aegypti, Aedes albopictus, Larval ecology, Transmission risk, Republic of the Congo

\footnotetext{
*Correspondence: kamgang_d@yahoo.fr; basile.kamgang@crid-cam.net

${ }^{\dagger}$ Theodel A. Wilson-Bahun and Basile Kamgang contributed equally to this work

${ }^{1}$ Centre for Research in Infectious Diseases (CRID), P.O. Box 13591,

Yaoundé, Cameroon

Full list of author information is available at the end of the article
}

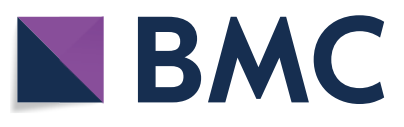

(c) The Author(s) 2020. This article is licensed under a Creative Commons Attribution 4.0 International License, which permits use, sharing, adaptation, distribution and reproduction in any medium or format, as long as you give appropriate credit to the original author(s) and the source, provide a link to the Creative Commons licence, and indicate if changes were made. The images or other third party material in this article are included in the article's Creative Commons licence, unless indicated otherwise in a credit line to the material. If material is not included in the article's Creative Commons licence and your intended use is not permitted by statutory regulation or exceeds the permitted use, you will need to obtain permission directly from the copyright holder. To view a copy of this licence, visit http://creativeco mmons.org/licenses/by/4.0/. The Creative Commons Public Domain Dedication waiver (http://creativecommons.org/publicdomain/ zero/1.0/) applies to the data made available in this article, unless otherwise stated in a credit line to the data. 


\section{Background}

Mosquito-borne diseases such as dengue, chikungunya, yellow fever and Zika are increasing concerns in most tropical and sub-tropical regions. Dengue fever is the most important of these diseases worldwide. One last estimate indicates that, around 390 million dengue infections occur annually leading to 96 million (67-136 million) clinical cases [1]. In 2016, Zika virus was declared as a health emergency of international concern by WHO [2] because of the association of this virus with microcephaly [3], Guillain-Barré syndrome [4] and myelitis [5]. The burden of these arbovirus infections in Africa remains unknown except for yellow fever that a modelling study based on Africa data sources estimated in 2013, 84,000170,000 severe cases, of which $29,000-60,000$ were fatal [6]. Formerly, dengue, Zika, and chikungunya were considered as scarce in West-Central Africa despite of the presence of major vector Aedes aegypti Linnaeus. However, in the past decade, several outbreaks caused by these viruses have been reported in West-Central African countries [7-14] suggesting a possible change in the dynamics of these diseases. These viruses are transmitted to vertebrates including humans mainly by the bite of an infected mosquito belonging to the genus Aedes notably Ae. aegypti and Aedes albopictus (Skuse). Aedes aegypti is native from Africa forests [15], and is nowadays found in sylvan and human-dominated environments. Two subspecies of Ae. aegypti were formally identified by Mattingly [16]. The dark form, Ae. aegypti formosus, confined to the African forest and the light form, Ae. aegypti aegypti, found in human-dominated habitats primarily outside Africa [16]. The Sylvan population of Ae. aegypti breed in natural containers such as rock pools, tree holes and leaf axils [16-18] and rarely feed on humans [15], whereas domestic populations feed mainly on humans, mate and rest indoors, breed in man-made containers in and around human dwellings [19]. Generally, Ae. aegypti collected in Central Africa whatever the environment matches Ae. aegypti formosus [20, 21] suggesting that in Central Africa, two types of Ae. aegypti formosus, domestic and sylvan, co-occur. On the other hand, Ae. albopictus, originated from south east Asian forest, has invaded all the continents in past 30-40 decades [22]. This species was first reported in Central Africa in the early 2000s [23], and nowadays, is present in almost all countries of the region including the Republic of the Congo $[24,25]$. Aedes albopictus is the dominant species of Aedes in most urban areas located under $6^{\circ} \mathrm{N}$ in Central Africa where it tends to replace the native species Ae. aegypti [25-28]. The coexistence of Ae. aegypti and Ae. albopictus sharing often the same larval habitats has been documented in Central Africa [26, 27, 29, 30]. Nevertheless, it was demonstrated that Ae. aegypti prefers man-made containers located in areas with high building density while Ae. albopictus rather prefers larval habitats surrounded by vegetation $[27,30,31]$. Interestingly, the emergence of dengue, Zika and chikungunya outbreaks in urban areas in Central Africa coincided with the invasion of the region by Ae. albopictus [32]. Indeed, Ae. albopictus was detected as the main vector during a concurrent dengue/chikungunya outbreak in Gabon in 2007 [9, 33]. Both Ae. aegypti and Ae. albopictus were found infected with chikungunya virus during the massive outbreak that occurred in Brazzaville in 2011 with 11,000 cases [13, $24]$. Recently in 2019, Ae albopictus was suspected as the main vector during the chikungunya outbreak affecting several locations in the Republic of the Congo [34]. It was also demonstrated that both Ae. aegypti and Ae. albopictus collected in Brazzaville are able to transmit yellow fever virus [35], Zika virus [36], and dengue virus [37]. As there is no efficient vaccine (apart from yellow fever) and specific treatment against these diseases, vector control remains the cornerstone to prevent outbreaks. However, implementing vector control strategies requires extensive background information on the larval ecology of Aedes species. However, in the Republic of the Congo, no such data are available apart from preliminary studies showing the co-occurrence of Ae. aegypti and Ae. albopictus across the country with a predominance of Ae. albopictus in all locations except in Brazzaville [25] and the dominance of Ae. albopictus in two periurban neighbourhoods from Brazzaville irrespective of the season [38]. Here, we present an extensive analysis of the levels of infestation, detailed comparative data of larval ecology, and geographical distribution of Ae. aegypti and Ae. albopictus in Brazzaville, the capital city of the Republic of the Congo to improve the control of these vectors and help prevent other arbovirus outbreaks in this major city.

\section{Methods \\ Study area}

Surveys were carried out in Brazzaville $\left(4^{\circ} 16^{\prime} 04^{\prime \prime} \mathrm{S}\right.$, $\left.15^{\circ} 16^{\prime} 31^{\prime \prime} \mathrm{E}\right)$, the capital city of the Republic of the Congo (Fig. 1). The city is located along the Congo River and spans an area of $263.9 \mathrm{~km}^{2}$ with a population estimation of 1.4 million inhabitants. Brazzaville is laid out concentrically: the downtown is modern with urban buildings containing most administrative and commercial structures, while the suburb is unplanned and sparsely populated. Brazzaville is subdivided into 9 boroughs: Makélékélé; Bacongo; Poto-Poto; Moungali; Ouenzé; Talangaï; M'filou; Madibou; and Djiri. Each borough comprises several neighbourhoods. The climate is humid tropical with four seasons: a short dry season from January to February; a short rainy season from March to May; a long dry season from June to September; and a 


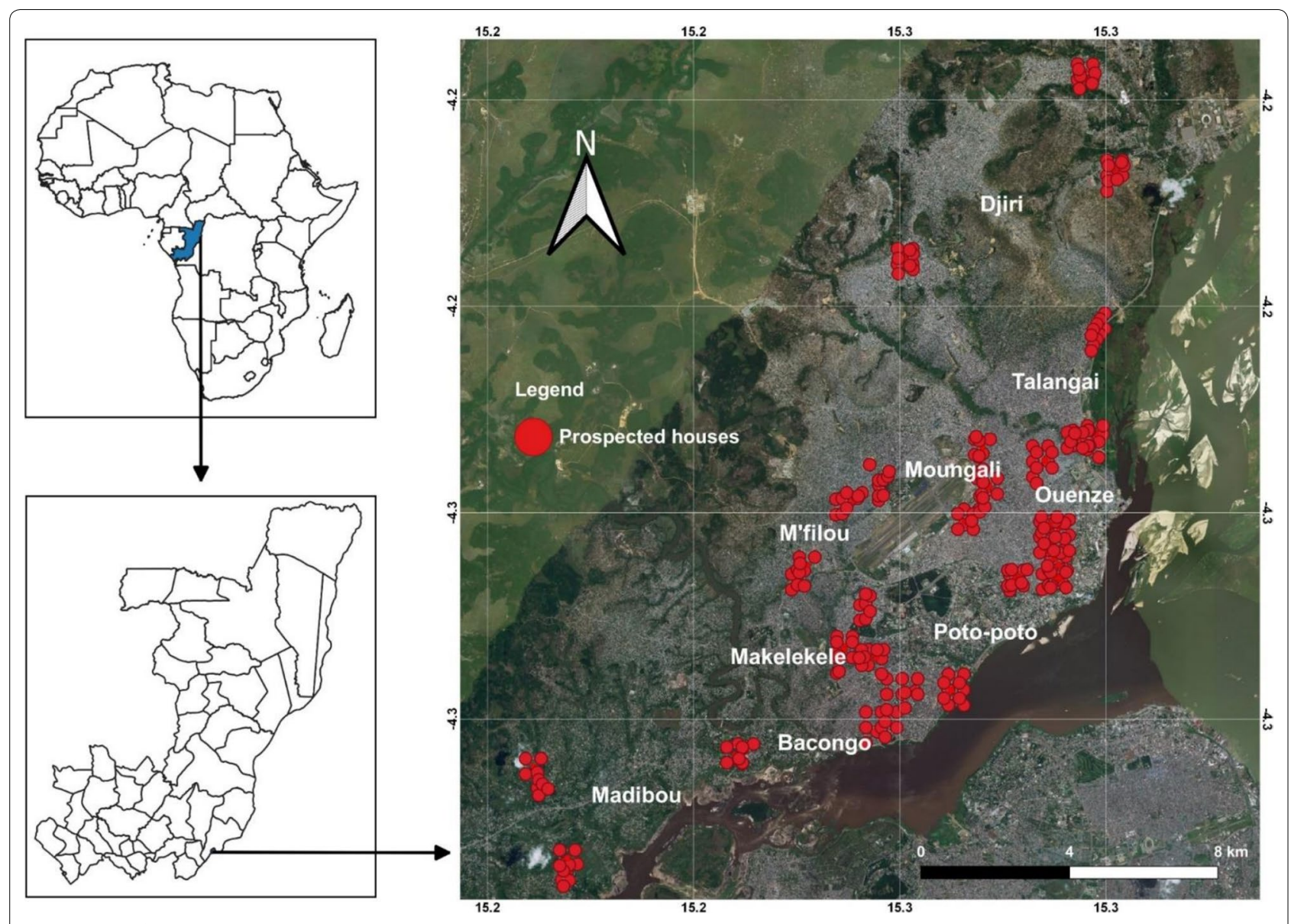

Fig. 1 Map of Brazzaville indicating mosquito sampling sites

long rainy season from October to December. The mean annual precipitation ranges between $1500-1800 \mathrm{~mm}$ and the mean annual temperature is $25^{\circ} \mathrm{C}$ [39].

\section{Sampling and entomological surveys}

Entomological investigations were carried out in November/December 2017, corresponding to the long rainy season period in which Aedes mosquitoes are at maximum densities. Surveys were undertaken in clusters of dwellings sampled randomly. Each cluster consisted of 10 dwellings per neighbourhood randomly selected (by drawing lots). In each borough, 3 neighbourhoods were randomly selected by drawing lots, and boroughs were categorized, based on geographical position, the downtown (city centre with high building density) or suburb (periphery area of the city characterised by high vegetation density compare to downtown). The downtown is located in Poto-Poto, Moungali, and Ouenzé boroughs, while the suburb is located in Makélékélé, Bacongo,
M'filou, Madibou, Talangaï and Djiri. Two rural neighbourhoods were surveyed in Madibou (Fig. 1, Table 1). During the surveys, each selected dwelling was geo-referenced with a global positioning system (GPS, Garmin Etrex 10), surveyed to record all natural and/or artificial containers with water (potential containers), and those containing at least one larvae or pupae (positive containers). Positive larval habitats were also geo-referenced. For each potential/positive container, the type of container, the volume of container (low, $<5 \mathrm{l}$; medium, 5-50 l; and high, $>50 \mathrm{l}$ ) the volume of water inside the container (low, < $5 \mathrm{l}$; medium, 5-50 l; and high, > $50 \mathrm{l}$ ), the source of the water inside the container (tap or rain) and the quality of water [clear; turbid (cloudy water), and polluted (foul smelling water with organic matter and/ or with the presence of a layer of oil)] inside the container, the presence of plant debris inside the container, the presence of the vegetation (grass, tree or shrub) in the immediate vicinity of the container, the shade (full, partial or none), the colour (transparent, dark or light 
Table 1 Location of surveyed boroughs and neighbourhoods in Brazzaville

\begin{tabular}{|c|c|c|c|c|}
\hline \multirow{2}{*}{$\frac{\text { Borough }}{\text { Bacongo }}$} & \multirow{2}{*}{$\begin{array}{l}\text { Neighbourhood } \\
\text { Mpissa }\end{array}$} & \multicolumn{2}{|c|}{ Geographical coordinates } & \multirow{2}{*}{$\begin{array}{l}\text { Location } \\
\text { Suburb }\end{array}$} \\
\hline & & $04^{\circ} 18^{\prime} 186^{\prime \prime} \mathrm{S}$ & $015^{\circ} 14^{\prime} 668^{\prime \prime} \mathrm{E}$ & \\
\hline & $\begin{array}{l}\text { Saint Pierre } \\
\text { Clavaire }\end{array}$ & $04^{\circ} 17^{\prime} 614^{\prime \prime} S$ & $015^{\circ} 14^{\prime} 998^{\prime \prime} \mathrm{E}$ & Suburb \\
\hline & Dahomey & $04^{\circ} 17^{\prime} 429^{\prime \prime} S$ & $015^{\circ} 15^{\prime} 854^{\prime \prime} \mathrm{E}$ & Suburb \\
\hline \multirow[t]{3}{*}{ Makélékélé } & Ngangouoni & $04^{\circ} 16^{\prime} 890^{\prime \prime} \mathrm{S}$ & $015^{\circ} 14^{\prime} 222^{\prime \prime} \mathrm{E}$ & Suburb \\
\hline & $\begin{array}{l}\text { Mokondzi } \\
\text { Ngouaka }\end{array}$ & $04^{\circ} 17^{\prime} 100^{\prime \prime} S$ & $015^{\circ} 14^{\prime} 688^{\prime \prime} \mathrm{E}$ & Suburb \\
\hline & Diata & $04^{\circ} 16^{\prime} 349^{\prime \prime} \mathrm{S}$ & $015^{\circ} 14^{\prime} 437^{\prime \prime} \mathrm{E}$ & Suburb \\
\hline \multirow[t]{3}{*}{ Poto-Poto } & Tsinguidi & $04^{\circ} 15^{\prime} 893^{\prime \prime} \mathrm{S}$ & $015^{\circ} 16^{\prime} 581^{\prime \prime} \mathrm{E}$ & Downtown \\
\hline & Quartier 31 & $04^{\circ} 16^{\prime} 030^{\prime \prime} S$ & $015^{\circ} 17^{\prime} 155^{\prime \prime} \mathrm{E}$ & Downtown \\
\hline & Quartier 32 & $04^{\circ} 15^{\prime} 773^{\prime \prime} S$ & $015^{\circ} 17^{\prime} 309^{\prime \prime} \mathrm{E}$ & Downtown \\
\hline \multirow[t]{3}{*}{ Moungali } & 10 maisons & $04^{\circ} 14^{\prime} 499^{\prime \prime} \mathrm{S}$ & $015^{\circ} 16^{\prime} 115^{\prime \prime} \mathrm{E}$ & Downtown \\
\hline & Matsoua & $04^{\circ} 14^{\prime} 783^{\prime \prime} S$ & $015^{\circ} 16^{\prime} 147^{\prime \prime} \mathrm{E}$ & Downtown \\
\hline & Mounkondo & $04^{\circ} 14^{\prime} 186^{\prime \prime} \mathrm{S}$ & $015^{\circ} 16^{\prime} 167^{\prime \prime} \mathrm{E}$ & Downtown \\
\hline \multirow[t]{3}{*}{ Ouenzé } & Quartier 51 & $04^{\circ} 15^{\prime} 182^{\prime \prime} \mathrm{S}$ & $015^{\circ} 17^{\prime} 335^{\prime \prime} \mathrm{E}$ & Downtown \\
\hline & Quartier 52 & $04^{\circ} 15^{\prime} 282^{\prime \prime} \mathrm{S}$ & $015^{\circ} 17^{\prime} 151^{\prime \prime} \mathrm{E}$ & Downtown \\
\hline & Bouemba & $04^{\circ} 14^{\prime} 115^{\prime \prime} S$ & $015^{\circ} 17^{\prime} 041^{\prime \prime} \mathrm{E}$ & Downtown \\
\hline \multirow[t]{3}{*}{ Talangaï } & Fleuve Congo & $04^{\circ} 13^{\prime} 960^{\prime \prime} S$ & $015^{\circ} 17^{\prime} 818^{\prime \prime} \mathrm{E}$ & Suburb \\
\hline & Quartier 64 & $04^{\circ} 13^{\prime} 912^{\prime \prime} \mathrm{S}$ & $015^{\circ} 17^{\prime} 645^{\prime \prime} \mathrm{E}$ & Suburb \\
\hline & Quartier 68 & $04^{\circ} 12^{\prime} 212^{\prime \prime S}$ & $015^{\circ} 17^{\prime} 891^{\prime \prime} \mathrm{E}$ & Suburb \\
\hline \multirow[t]{3}{*}{ M'filou } & Moutabala & $04^{\circ} 15^{\prime} 907^{\prime \prime} \mathrm{S}$ & $015^{\circ} 13^{\prime} 402^{\prime \prime} \mathrm{E}$ & Suburb \\
\hline & Indzuli & $04^{\circ} 14^{\prime} 890^{\prime \prime} \mathrm{S}$ & $015^{\circ} 14^{\prime} 152^{\prime \prime} \mathrm{E}$ & Suburb \\
\hline & Ngambio & $04^{\circ} 14^{\prime} 698^{\prime \prime} S$ & $015^{\circ} 14^{\prime} 724^{\prime \prime} \mathrm{E}$ & Suburb \\
\hline \multirow[t]{3}{*}{ Madibou } & Kombé & $04^{\circ} 20^{\prime} 226^{\prime \prime} S$ & $015^{\circ} 10^{\prime} 098^{\prime \prime} \mathrm{E}$ & Rural \\
\hline & Kibina & $04^{\circ} 18^{\prime} 668^{\prime \prime} S$ & $015^{\circ} 09^{\prime} 665^{\prime \prime} \mathrm{E}$ & Rural \\
\hline & Mafouta & $04^{\circ} 18^{\prime} 461^{\prime \prime} \mathrm{S}$ & $015^{\circ} 12^{\prime} 747^{\prime \prime} \mathrm{E}$ & Suburb \\
\hline \multirow[t]{3}{*}{ Djiri } & Manianga & $04^{\circ} 09^{\prime} 983^{\prime \prime} \mathrm{S}$ & $015^{\circ} 18^{\prime} 111^{\prime \prime} \mathrm{E}$ & Suburb \\
\hline & Makabandilou & $04^{\circ} 08^{\prime} 552^{\prime \prime} \mathrm{S}$ & $015^{\circ} 17^{\prime} 693^{\prime \prime} \mathrm{E}$ & Suburb \\
\hline & Matari & $04^{\circ} 11^{\prime} 295^{\prime \prime} \mathrm{S}$ & $015^{\circ} 15^{\prime} 078^{\prime \prime} \mathrm{E}$ & Suburb \\
\hline
\end{tabular}

colour) of the container, the material (metal, plastic, rubber or miscellaneous), the distance between the container and the nearest building $(0-5 \mathrm{~m}, 5-10 \mathrm{~m})$, the distance of container to the nearest plant (grass, tree or shrub) $(0-5 \mathrm{~m}, 5-10 \mathrm{~m})$ and to the ground $(0-1 \mathrm{~m}$, 1-3 m) were noted as well the number of inhabitants per dwelling. On basis of the nature, the source, and the use of the water, potential containers were classified into three categories: domestic; peridomestic; and natural. Domestic containers (e.g. storage tanks) were defined as human-filled receptacles, while peridomestic (e.g. discarded tanks and used tyres), and natural receptacles (e.g. rock and tree holes, leaf axils) were those filled by rain [27]. Larvae and pupae found per container were collected, referenced and transported to the insectary and isolated from predators such as Culex (Lutzia) tigripes. Pupae per container were counted, isolated to larvae, and maintained until emergence to adults. Larvae were also reared to adults. Emerged adults per larval habitat were morphologically identified using a suitable taxonomic key $[40,41]$. The proportion of larvae and pupae, or pupae of each Aedes species was estimated based on the number of specimens identified for each species divided by the total number of larvae and pupae, or pupae of Aedes spp. identified.

\section{Entomological indices}

The level of infestation was estimated using traditional Stegomyia indices including the Breteau index (BI, the number of positive containers per 100 surveyed houses), house index (HI, the percentage of houses infested), and container index (CI, percentage of positive containers). Estimated thresholds of $\mathrm{HI}, \mathrm{BI}$ and $\mathrm{CI}$ references were established by the WHO for dengue and yellow fever transmission. Whenever $\mathrm{HI}>35 \%, \mathrm{BI}>50$, and $\mathrm{CI}>20 \%$, the city is considered as high risk of urban transmission of yellow fever virus, whereas $\mathrm{HI}<4 \%, \mathrm{BI}<5$ and $\mathrm{CI}<3 \%$, indicated that the city is considered as low risk of the disease transmission [42]. Similarly, low $\mathrm{HI}<0.1 \%$, medium $\mathrm{HI} 0.1-5 \%$ and high $\mathrm{HI}>5 \%$ were established for dengue transmission [43]. Additional indices based on absence/presence and number of pupae were also used including pupae index (PI, number of pupae per 100 surveyed houses) and pupae per person index (PPI, number of pupae per 100 inhabitants). The productivity of pupae in each container type was also assessed as defined (the number of pupae in each container type divided by the total number of pupae in all container types) [44].

\section{Data analysis}

All statistical analyses were performed using $\mathrm{R}$ version 3.1.5 [45] and $R$ studio version 1.1.463, at $\alpha=0.05$ level of significance. Variables defined as categorical variables were expressed by percentages and confidence intervals, and numeric variables were expressed by means and standard deviations. The Shapiro-Wilk test for normality was used to assess the distribution of the data. Because data were not normally distributed, non-parametric statistical tests were used to compare variables; Chi-square test was used for percentages and Wilcoxon rank sum test for means. A binary logistic regression model was used to assess the relationship between larval habitat characteristics and presence of immature stages (larvae and pupae) or pupae only of each Aedes species (Additional file 1: Table S1). Odds ratios (OR) and their 95\% confidence intervals ( $95 \% \mathrm{CI})$ were estimated. While a negative binomial regression model was used to assess the relationship between larval habitat characteristics (Additional file 1: Table S1) and number of immature stages and pupae only of Aedes spp. (based on estimates and their standard deviations). Both models were computed first with all 
factors related to the larval habitat and the environment, and then, each model was refined using a stepwise procedure based on Akaike's information criterion (AIC) [46]. The GPS coordinates of each surveyed house, and each positive container of both species, were projected onto a map using the open-source software QGIS (version 3.4.1 Madeira) [47].

\section{Results}

\section{Pre-imaginal infestation}

In total, 268 dwellings were surveyed in 27 neighbourhoods across Brazzaville, with 3076 inhabitants (Table 2). Among the surveyed dwellings, 111 (41.4\%) were found positive, harbouring at least one positive container of Aedes (larva and/or pupa) (Table 2). A total of 3787 specimens of immature stages of Aedes were collected,

Table 2 Levels of infestation of Aedes spp. in different locations in Brazzaville

\begin{tabular}{|c|c|c|c|c|c|c|c|}
\hline \multirow[t]{2}{*}{ Location } & \multirow{2}{*}{$\begin{array}{l}\text { Inhabitants } \\
\text { n }\end{array}$} & \multicolumn{2}{|l|}{ Dwellings } & \multirow{2}{*}{$\begin{array}{l}\text { Aedes spp. } \\
n\end{array}$} & \multirow{2}{*}{$\begin{array}{l}\text { Ae. aegypti } \\
n\end{array}$} & \multirow{2}{*}{$\begin{array}{l}\text { Ae. albopictus } \\
n\end{array}$} & \multirow{2}{*}{$\begin{array}{l}\text { Ae. vittatus } \\
n\end{array}$} \\
\hline & & Surveyed & Positive & & & & \\
\hline Bacongo & 369 & 30 & 9 & 285 & 3 & 282 & 0 \\
\hline Mpissa & 137 & 10 & 4 & 233 & 1 & 232 & 0 \\
\hline Saint Pierre Clavaire & 129 & 10 & 4 & 34 & 0 & 34 & 0 \\
\hline Dahomey & 103 & 10 & 1 & 18 & 2 & 16 & 0 \\
\hline Makélékélé & 287 & 28 & 13 & 364 & 34 & 330 & 0 \\
\hline Ngangouoni & 82 & 10 & 7 & 133 & 9 & 124 & 0 \\
\hline Mokondzi Ngouaka & 118 & 10 & 2 & 72 & 0 & 72 & 0 \\
\hline Diata & 87 & 8 & 4 & 159 & 25 & 134 & 0 \\
\hline Poto-Poto & 400 & 30 & 18 & 563 & 532 & 31 & 0 \\
\hline Tsinguidi & 130 & 10 & 5 & 146 & 121 & 25 & 0 \\
\hline Quartier 31 & 128 & 10 & 5 & 118 & 118 & 0 & 0 \\
\hline Quartier 32 & 142 & 10 & 8 & 299 & 293 & 6 & 0 \\
\hline Moungali & 496 & 30 & 13 & 661 & 341 & 320 & 0 \\
\hline 10_maisons & 147 & 10 & 6 & 435 & 264 & 171 & 0 \\
\hline Matsoua & 149 & 10 & 2 & 43 & 24 & 19 & 0 \\
\hline Mounkondo & 200 & 10 & 5 & 183 & 53 & 130 & 0 \\
\hline Ouenzé & 327 & 30 & 14 & 892 & 805 & 87 & 0 \\
\hline Quartier 51 & 107 & 10 & 6 & 416 & 333 & 83 & 0 \\
\hline Quartier 52 & 105 & 10 & 6 & 318 & 316 & 2 & 0 \\
\hline Bouemba & 115 & 10 & 2 & 158 & 156 & 2 & 0 \\
\hline Talangaï & 411 & 30 & 11 & 276 & 80 & 196 & 0 \\
\hline Fleuve Congo & 161 & 10 & 5 & 166 & 22 & 144 & 0 \\
\hline Quartier 64 & 131 & 10 & 4 & 89 & 58 & 31 & 0 \\
\hline Quartier 68 & 119 & 10 & 2 & 21 & 0 & 21 & 0 \\
\hline Mfilou & 299 & 30 & 12 & 210 & 10 & 200 & 0 \\
\hline Moutabala & 104 & 10 & 4 & 118 & 4 & 114 & 0 \\
\hline Indzuli & 101 & 10 & 5 & 39 & 3 & 36 & 0 \\
\hline Ngambio & 94 & 10 & 3 & 53 & 3 & 50 & 0 \\
\hline Madibou & 242 & 30 & 10 & 170 & 45 & 91 & 34 \\
\hline Kombé & 82 & 10 & 4 & 92 & 38 & 54 & 0 \\
\hline Kibina & 75 & 10 & 3 & 33 & 2 & 31 & 0 \\
\hline Mafouta & 85 & 10 & 3 & 45 & 5 & 6 & 34 \\
\hline Djiri & 305 & 30 & 11 & 366 & 143 & 223 & 0 \\
\hline Manianga & 93 & 10 & 2 & 103 & 94 & 9 & 0 \\
\hline Makabandilou & 88 & 10 & 7 & 201 & 41 & 160 & 0 \\
\hline Matari & 124 & 10 & 2 & 62 & 8 & 54 & 0 \\
\hline Total & 3136 & 268 & 111 & 3787 & 1993 & 1760 & 34 \\
\hline
\end{tabular}

Abbreviation: $n$, number of inhabitants and Aedes species per neighbourhoods and boroughs 
comprising of 1993 (52.6\%) Ae. aegypti, 1760 (46.5\%) Ae. albopictus and 34 (0.9\%) Ae. vittatus Bigot, 1861. Nevertheless, several other species were also found in association with these Aedes species, notably Anopheles gambiae Giles, 1902 (s.l.) (6 specimens), Culex tigripes De Grandpré \& De Charmoy, 1900 (107 specimens) and Culex spp. (216 specimens).

\section{Types and prevalence of water-holding containers}

A total of 455 potential breeding containers for Aedes spp. were surveyed, of which 176 (38.7\%) were positive for immature stages of Aedes spp. (Table 3). Containers found during the surveys were grouped into three categories and five types (Table 3): domestic containers (water storage tanks, and flower-pots); peridomestic containers (discarded tanks, used tyres, and miscellaneous); and natural containers (axils of plants). Analysis revealed that Ae. albopictus (mean \pm SD: $4.9 \pm 1.2$ ) was significantly more abundant than Ae. aegypti (mean \pm SD: $3.6 \pm 1.9$ ) in used tyres (Wilcoxon rank sum test: $W=2199, P=0.007$ ) (Fig. 2). However, no significant difference was found in the prevalence of both species in the other container types (Wilcoxon rank sum test: $W=18094$, $P>0.05$ ) (Fig. 2). Discarded tanks were the most prevalent (Table 3), and the most productive water-holding container type for both Ae. aegypti (56.4\% of pupae) and Ae. albopictus (53.1\% of pupae) (Fig. 2). Nevertheless, no significant difference was observed in the pupae abundance of both species according to the container type (Wilcoxon rank sum test: $W=17414$, $P>0.05)$ except for used tyres where Ae. albopictus pupae abundance (mean \pm SD: $2.0 \pm 0.6$ ) was significantly higher (Wilcoxon rank sum test: $W=2050$, $P=0.013$ ) than those of Ae. aegypti (mean $\pm \mathrm{SD}$ : $1.3 \pm 0.7$ ) (Fig. 2).

\section{Risk factors for the presence and the abundance of Aedes species}

Binary logistic regression analysis showed that several factors influence the presence of immature stages of Ae. aegypti and Ae. albopictus as well as the presence of pupae of both species (Table 4). Indeed, the turbid aspect of water (OR: 2.38, 95\% CI: 1.29-4.41, $P=0.005$ ), the location of neighbourhoods (suburb and rural) (OR: 0.12, 95\% CI: $0.071-0.22, P<0.0001$ and OR: $0.11,95 \%$ CI: 0.03-0.30, $P<0.0001$, respectively), the presence of surrounding vegetation (OR: 2.89, 95\% CI: 1.59-5.44, $P=0.0007)$, and the container colour (transparent) (OR: $0.25,95 \%$ CI: $0.07-0.94, P=0.03$ ) were significantly associated with the presence of immature stages of $A e$. aegypti whereas only the turbid aspect of water (OR: 2.06, 95\% CI: $1.20-3.53, P=0.008)$, and the presence of surrounding vegetation (OR: $2.97,95 \%$ CI: $1.77-5.08$, $P<0.0001)$ was significantly associated with the presence of immature stages of Ae. albopictus (Table 4). The presence of pupae of $A e$. aegypti was significantly associated with the turbid aspect of water (OR: 2.54, 95\% CI: $1.24-$ $5.19, P=0.01$ ), the location of neighbourhoods (suburb and rural) (OR: 0.07, 95\% CI: 0.03-0.15, $P<0.0001$ and OR: $0.08,95 \%$ CI: $0.02-0.27, P=0.0002$, respectively), the presence of surrounding vegetation (OR: 5.81, 95\% CI: 2.75-13.14, $P<0.0001$ ), the container colour (light and transparent) (OR: $0.25,95 \% \mathrm{CI}: 0.08-0.85, P=0.02$ and OR: $0.14,95 \% \mathrm{CI}: 0.03-0.60, P=0.007$, respectively) the source of water inside de container (tap) (OR: 0.38, 95\% CI: $0.15-0.89, P=0.03)$ and the material of the container (OR: $0.08,95 \%$ CI: $0.02-0.38, P=0.001$ ) whereas that of Ae. albopictus was significantly associated to the turbid aspect of water (OR: 2.28, 95\% CI: 1.23-4.16, $P=0.03$ ), and the location of neighbourhood (suburb) (OR: $1.93,95 \%$ CI: $1.03-3.74, P=0.04$ ) (Table 5).

Furthermore, negative binomial regression was used to explore the factors which can influence the number of pupae of Ae aegypti and Ae. albopictus inside the containers. Analysis revealed that the number of pupae of $A e$. aegypti was positively influenced by the source of water (tap) (estimate $=4.06, P=0.0003$ ), the presence of plant residues inside the container (estimate $=9.33$, $P<0.0001$ ), the presence of surrounding vegetation (estimate $=15.56, P<0.0001)$, the volume of water inside the container (estimate $=4.79, P<0.0001$ ), the container volume (estimate $=23.68, P<0.0001$ ), the distance to the nearest plant $(0-5 \mathrm{~m}$ and $5-10 \mathrm{~m})$ (estimate $=19.56, P$ $<0.0001$ and estimate $=18.94, P<0.0001$, respectively), the distance to the nearest building (5-10 meters) (estimate $=5.69, P<0.0001)$, the distance to ground $(1-3$ m) (estimate $=4.94, P=0.03$ ), and the neighbourhood location (rural) (estimate $=3.55, P=0.003$ ). The number of pupae of Ae. albopictus was also positively influenced by the turbid aspect of water (estimate $=1.98, P$ $<0.0001$ ), the presence of surrounding vegetation (estimate $=1.47, P=0.0004)$, and the neighbourhood location (suburb) (estimate $=1.38, P=0.001)($ Table 6). In contrast, the container colour (light and transparent) (estimate $=-11.27, P<0.0001$ and estimate $=-38.44$, $P<0.0001$, respectively), the absence of shade (estimate $=-9.75, P<0.0001)$, but also the volume of water inside the container (estimate $=-84.72, P<0.0001$ ), the container volume (estimate $=-13.92, P<0.0001)$ and the neighbourhood location (suburb) (estimate $=-25.81, P$ $<0.0001$ ) were inversely associated to the number of $A e$. aegypti pupae. While abundance of Ae albopictus pupae was negatively associated to the absence of shade (estimate $=-1.12, P=0.005)$ and the distance to nearest building (estimate $=-1.69, P=0.001)$ (Table 6). 
Table 3 Typology of containers and level of infestation of each container by Ae. aegypti and Ae. albopictus in Brazzaville

\begin{tabular}{|c|c|c|c|c|c|c|c|}
\hline \multirow[t]{3}{*}{ Location } & \multicolumn{6}{|c|}{ Container types } & \multirow{3}{*}{$\begin{array}{l}\text { Total } \\
n(\%)\end{array}$} \\
\hline & \multicolumn{2}{|l|}{ Domestic } & \multicolumn{3}{|l|}{ Peridomestic } & \multirow{2}{*}{$\begin{array}{l}\text { Natural } \\
\text { Axils of plants } \\
n(\%)\end{array}$} & \\
\hline & $\begin{array}{l}\text { Storage tanks } \\
n(\%)\end{array}$ & $\begin{array}{l}\text { Flower-pots } \\
n(\%)\end{array}$ & $\begin{array}{l}\text { Discarded tanks } \\
n(\%)\end{array}$ & $\begin{array}{l}\text { Miscellaneous } \\
n(\%)\end{array}$ & $\begin{array}{l}\text { Used tyres } \\
n(\%)\end{array}$ & & \\
\hline Bacongo & $7(42.8)$ & $1(0)$ & $17(52.9)$ & $3(33.3)$ & $5(80.0)$ & $0(0)$ & $33(51.5)$ \\
\hline Mpissa & $4(75.0)$ & $0(0)$ & $8(50.0)$ & $1(100)$ & $2(100)$ & $0(0)$ & 15 (66.6) \\
\hline Saint Pierre Clavaire & $0(0)$ & $1(0)$ & $6(50.0)$ & $2(0)$ & $3(66.6)$ & $0(0)$ & $12(41.6)$ \\
\hline Dahomey & $3(0)$ & $0(0)$ & $3(66.6)$ & $0(0)$ & $0(0)$ & $0(0)$ & $6(33.3)$ \\
\hline Makélékélé & $9(44.4)$ & $6(66.6)$ & $14(35.7)$ & $11(36.6)$ & $11(36.6)$ & $0(0)$ & $51(41.2)$ \\
\hline Ngangouoni & $9(44.4)$ & $2(50.0)$ & $5(60.0)$ & $3(33.33)$ & $7(42.8)$ & $0(0)$ & $26(46.1)$ \\
\hline Mokondzi Ngouaka & $0(0)$ & $2(50.0)$ & $2(0)$ & $1(100)$ & $2(0)$ & $0(0)$ & $7(28.6)$ \\
\hline Diata & $0(0)$ & $2(100)$ & $7(28.6)$ & $7(28.6)$ & $2(50.0)$ & $0(0)$ & $18(38.8)$ \\
\hline Poto-Poto & $18(27.8)$ & $13(61.5)$ & $26(42.3)$ & $1(0)$ & $10(30.0)$ & $0(0)$ & 68 (39.7) \\
\hline Tsinguidi & $4(0)$ & $5(60.0)$ & $12(25.0)$ & $0(0)$ & $2(0)$ & $0(0)$ & $23(26.1)$ \\
\hline Quartier 31 & $0(0)$ & $5(60.0)$ & $7(42.8)$ & $1(0)$ & $3(33.3)$ & $0(0)$ & $16(43.7)$ \\
\hline Quartier 32 & $14(35.7)$ & $3(66.6)$ & $7(71.4)$ & $0(0)$ & $5(40.0)$ & $0(0)$ & $29(48.3)$ \\
\hline Moungali & $15(40.0)$ & $2(100)$ & $15(53.3)$ & $1(100)$ & $9(33.3)$ & $0(0)$ & $42(47.6)$ \\
\hline 10 maisons & $9(11.1)$ & $2(100)$ & $5(80.0)$ & $1(1)$ & $3(33.3)$ & $0(0)$ & $20(45.0)$ \\
\hline Matsoua & $3(100)$ & $0(0)$ & $5(0)$ & $0(0)$ & $1(0)$ & $0(0)$ & $9(33.3)$ \\
\hline Mounkondo & $3(66.6)$ & $0(0)$ & $5(80.0)$ & $0(0)$ & $5(40.0)$ & $0(0)$ & $13(61.5)$ \\
\hline Ouenzé & $18(38.8)$ & $5(80.0)$ & 12 (66.6) & $1(100)$ & $3(100)$ & $0(0)$ & 39 (58.9) \\
\hline Quartier 51 & $5(80.0)$ & $2(100)$ & $4(75.0)$ & $1(100)$ & $3(100)$ & $0(0)$ & 15 (86.6) \\
\hline Quartier 52 & $8(37.5)$ & $1(100)$ & $5(80.0)$ & $0(0)$ & $0(0)$ & $0(0)$ & $14(57.1)$ \\
\hline Bouemba & $5(0)$ & $2(50.0)$ & $3(33.3)$ & $0(0)$ & $0(0)$ & $0(0)$ & $10(20.0)$ \\
\hline Talangaï & $11(27.2)$ & $0(0)$ & $21(57.1)$ & $1(100)$ & $4(25.0)$ & $0(0)$ & 37 (45.9) \\
\hline Fleuve Congo & $0(0)$ & $0(0)$ & $12(50.0)$ & $0(0)$ & $4(25.0)$ & $0(0)$ & $16(43.7)$ \\
\hline Quartier 64 & $4(0)$ & $0(0)$ & $8(75.0)$ & $1(100)$ & $0(0)$ & $0(0)$ & $13(53.8)$ \\
\hline Quartier 68 & $7(42.8)$ & $0(0)$ & $1(0)$ & $0(0)$ & $0(0)$ & $0(0)$ & $8(37.5)$ \\
\hline Mfilou & $12(0)$ & $0(0)$ & $36(22.2)$ & $5(80.0)$ & $16(50.0)$ & $1(100)$ & $70(30.0)$ \\
\hline Moutabala & $12(0)$ & $0(0)$ & $11(36.4)$ & $0(0)$ & $2(100)$ & $1(100)$ & $26(26.9)$ \\
\hline Indzuli & $0(0)$ & $0(0)$ & $17(5.88)$ & $5(80.0)$ & $10(40.0)$ & $0(0)$ & $32(28.1)$ \\
\hline Ngambio & $0(0)$ & $0(0)$ & $8(37.5)$ & $0(0)$ & $4(50.0)$ & $0(0)$ & $12(41.6)$ \\
\hline Madibou & $9(0)$ & $6(0)$ & $33(27.3)$ & $2(50.0)$ & $8(37.5)$ & $0(0)$ & $58(22.4)$ \\
\hline Kombé & $0(0)$ & $2(0)$ & $14(28.6)$ & $1(100)$ & $2(50.0)$ & $0(0)$ & 19 (31.6) \\
\hline Kibina & $0(0)$ & $0(0)$ & $11(18.2)$ & $0(0)$ & $5(40.0)$ & $0(0)$ & $16(25.0)$ \\
\hline Mafouta & $9(0)$ & $4(0)$ & $8(37.5)$ & $1(0)$ & $1(0)$ & $0(0)$ & $23(13.0)$ \\
\hline Djiri & $25(8.0)$ & $1(100)$ & $20(55.0)$ & $5(0)$ & $6(50.0)$ & $0(0)$ & $57(29.8)$ \\
\hline Manianga & $2(0)$ & $0(0)$ & $6(50.0)$ & $1(0)$ & $0(0)$ & $0(0)$ & $9(33.3)$ \\
\hline Makabandilou & $2(50.0)$ & $1(100)$ & $13(53.8)$ & $3(0)$ & $4(50.0)$ & $0(0)$ & $23(20.9)$ \\
\hline Matari & $21(4.8)$ & $0(0)$ & $1(100)$ & $1(0)$ & $2(50.0)$ & $0(0)$ & $25(12.0)$ \\
\hline Total & $124(24.2)$ & 34 (55.9) & $194(41.7)$ & $30(43.3)$ & $72(40.3)$ & $1(100)$ & 455 (38.7) \\
\hline
\end{tabular}

Abbreviations: $n$, number of potential containers prospected; \%, denotes percentage of positive containers (infested by Aedes species)

\section{Spatial distribution of Aedes species in Brazzaville}

Both Ae. aegypti and Ae. albopictus were found across the city (Fig. 3a) while Ae. vittatus was collected only in one periurban borough (Madibou) (Table 2). Overall, Ae. aegypti (52.6\%) was significantly more prevalent (Wilcoxon rank sum test: $W=137840, P=0.02$ ) than
Ae. albopictus (46.5\%) throughout the city. However, when analysis was performed according to the borough, Ae. albopictus was significantly (Wilcoxon rank sum test: $W=177030, P<0.0001)$ more abundant than $A e$. aegypti in three boroughs (Bacongo, Makélékélé and M'filou), all located in the suburb of the city (Table 7). 

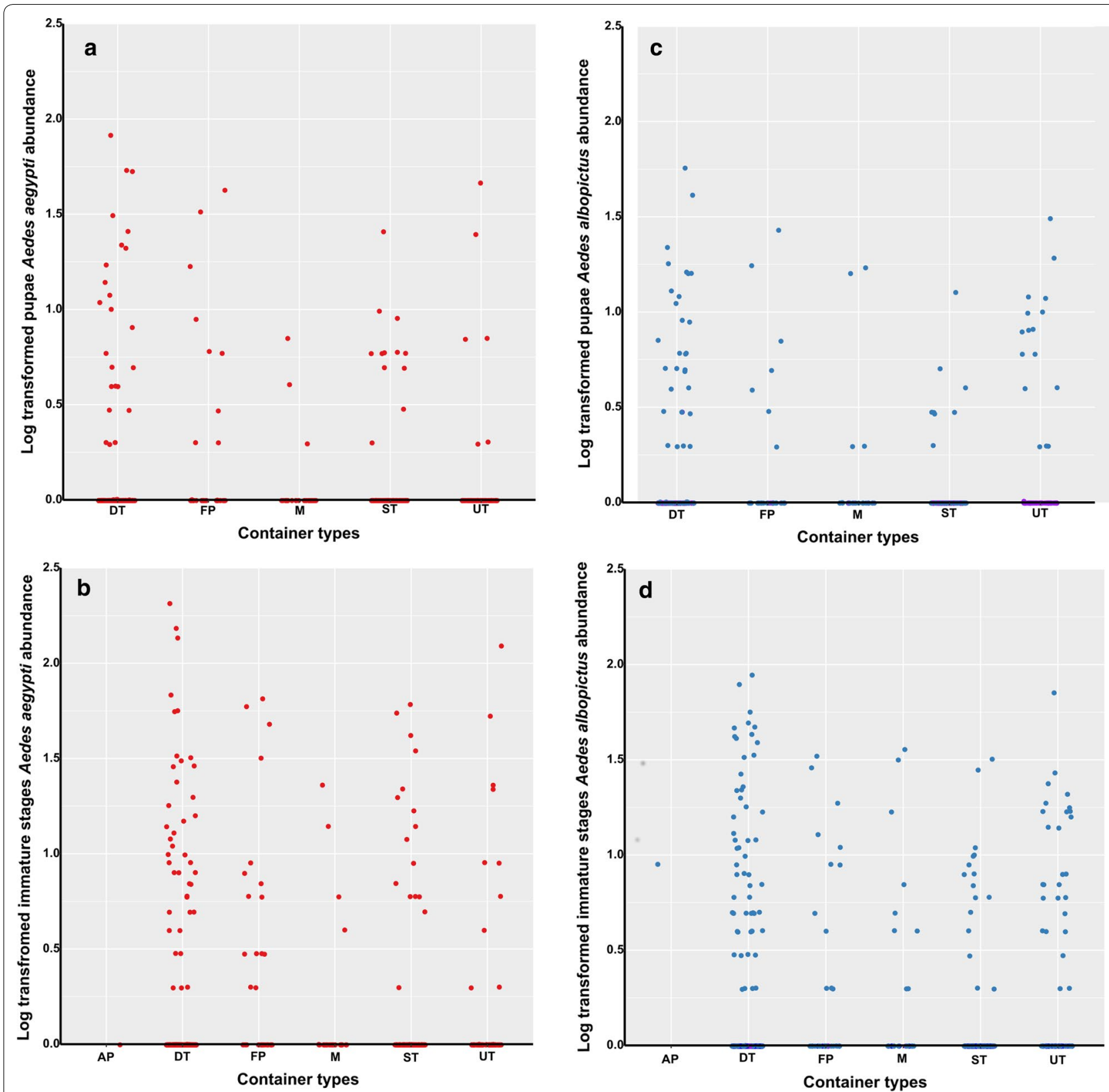

Fig. 2 Total abundance of pupae and of immature stages of Aedes aegypti $(\mathbf{a}, \mathbf{b})$ and Ae. albopictus (c, $\mathbf{d})$ per container type. Abbreviations: DT, discarded tanks; FP, flower-pots; M, miscellaneous; ST, storage tanks; and UT, used tires. Each dot represents the $\log _{10}$-transform of the abundance of containers infested by immature stages of Ae. albopictus and Ae. aegypti

Aedes aegypti, was significantly (Wilcoxon rank sum test: $W=177030, P<0.0001)$ more abundant than $A e$. albopictus only in two boroughs located in downtown, Poto-Poto (Ae. aegypti, $7.8 \pm 2.0$; Ae. albopictus, $0.5 \pm$ 0.2 ) and Ouenzé (Ae. aegypti, 20.6 $\pm 7.1 ;$ Ae. albopictus, $2.2 \pm 0.8$ ) (Fig. 3a, b; Table 7). On the other hand, no significant difference was detected for the prevalence of both Ae. aegypti and Ae. albopictus species respectively in four other boroughs: Moungali (located in downtown); Djiri; Madibou; and Talangaï (Wilcoxon rank sum test: $W=1505, P>0.05$ ) (Table 7). When an analysis was performed taking into account the environment, Ae. aegytpi (mean \pm SD: $6.60 \pm 1.38$ ) was significantly more abundant than Ae. albopictus (mean \pm SD: $3.00 \pm 0.53$ ) in downtown (Wilcoxon rank sum test: $W=13334, P=0.0003$ ) compared to suburb where $A e$. albopictus, (mean $\pm \mathrm{SD}: 3.5 \pm 0.6$ ) was significantly more abundant than Ae. aegypti (mean \pm SD: $0.9 \pm$ 
Table 4 Factors influencing the presence of larvae and/or pupae of Aedes aegypti and Aedes albopictus in the larval habitat

\begin{tabular}{|c|c|c|c|c|c|}
\hline \multirow[t]{2}{*}{ Factor } & \multirow[t]{2}{*}{ Modality } & \multicolumn{2}{|l|}{ Ae. aegypti } & \multicolumn{2}{|l|}{ Ae. albopictus } \\
\hline & & OR & $95 \% \mathrm{Cl}$ & OR & $95 \% \mathrm{Cl}$ \\
\hline \multirow[t]{3}{*}{ Neighbourhood location } & Downtown & Ref & Ref & Ref & Ref \\
\hline & Suburb & $0.12^{* * *}$ & $0.071-0.22$ & 1.37 & $0.84-0.29$ \\
\hline & Rural & $0.11^{* * *}$ & $0.03-0.30$ & 0.52 & $0.19-1.29$ \\
\hline \multirow[t]{6}{*}{ Container types } & Axils of plants & Ref & Ref & Ref & Ref \\
\hline & Discarded tanks & $3.75 \times 10^{6}$ & $1.73 \times 10^{-206}-\mathrm{na}$ & $5.05 \times 10^{-8}$ & $\mathrm{na}-1.15 \times 10^{205}$ \\
\hline & Flower-pots & $5.32 \times 10^{6}$ & $3.55 \times 10^{-206}-$ na & $4.85 \times 10^{-8}$ & na- $8.87 \times 10^{204}$ \\
\hline & Miscellaneous & $2.21 \times 10^{6}$ & $1.66 \times 10^{-206}-\mathrm{na}$ & $3.20 \times 10^{-8}$ & na-5.65 × $10^{204}$ \\
\hline & Storage tanks & $1.48 \times 10^{6}$ & $7.58 \times 10^{-207}-\mathrm{na}$ & $1.09 \times 10^{-8}$ & $\mathrm{na}-1.83 \times 10^{204}$ \\
\hline & Used tyres & $8.77 \times 10^{5}$ & $8.72 \times 10^{-207}-\mathrm{na}$ & $5.59 \times 10^{-8}$ & $\mathrm{na}-1.14 \times 10^{205}$ \\
\hline \multirow[t]{3}{*}{ Container colour } & Dark & Ref & Ref & na & na \\
\hline & Light & 0.62 & $0.21-1.94$ & na & na \\
\hline & Transparent & $0.25^{*}$ & $0.07-0.94$ & na & na \\
\hline \multirow[t]{3}{*}{ Water quality } & Clear & Ref & Ref & Ref & Ref \\
\hline & Turbid & $2.38^{* *}$ & $1.29-4.41$ & $2.06^{* *}$ & $1.20-3.53$ \\
\hline & Polluted & $1.69 \times 10^{-7}$ & na-9.71 $\times 10^{20}$ & $1.99 \times 10^{-7}$ & na-2.03 $\times 10^{23}$ \\
\hline \multirow[t]{2}{*}{ Water source } & Tap & na & na & 2.49 & $1.01-6.74$ \\
\hline & Rain & na & na & Ref & Ref \\
\hline \multirow[t]{2}{*}{ Presence of surrounding vegetation } & Yes & $2.89^{* * *}$ & $1.59-5.44$ & $2.97^{* * *}$ & $1.77-5.08$ \\
\hline & No & Ref & Ref & Ref & Ref \\
\hline \multirow[t]{2}{*}{ Distance to nearest building } & $0-5 \mathrm{~m}$ & na & na & Ref & Ref \\
\hline & $5-10 m$ & na & na & 0.57 & $0.29-1.08$ \\
\hline
\end{tabular}

${ }^{*} P<0.05,{ }^{* *} P<0.01,{ }^{* * *} P<0.0001$

Abbreviations: na, not applicable; OR, odd ratio; $\mathrm{Cl}, 95 \%$ confidence interval; Ref, reference (the reference for each factor were randomly selected by the software) is a comparator group, distances in meters $(\mathrm{m})$

0.3) (Wilcoxon rank sum test: $W=37334, P<0.0001$ ) (Fig. 3a, b; Table 7).

\section{Infestation indices}

Stegomyia and pupae indices are presented in Figs. 4, 5 and 6. Overall, the BI for Ae. aegypti and Ae. albopictus was $38.4 \%$ (95\% CI: $28.3-48.4 \%$ ) and $49.6 \%$ (95\% CI: 40.5-58.7\%) respectively, although the difference was not significant (Wilcoxon rank sum test: $W=3, P$ > 0.05) (Fig. 4a). Similarly, no significant difference (Wilcoxon rank sum test: $W=2, P>0.05$ ) was observed for $\mathrm{BI}$ values of Ae. aegypti and Ae. albopictus respectively in downtown (70\%, 95\% CI: 49.6-90.4\%; 40\%, 95\% CI: $24-56 \%)$ and in the suburb $(22.2 \%, 95 \%$ CI: $14.2-30.1 \%$; 54.5\%, 95\% CI: 41.7-67.4\%) (Fig. 4b). However, comparison of indices between both species according to the boroughs showed BI values for Ae. albopictus significantly higher compared to those for Ae. aegypti (Wilcoxon rank sum test: $W=2, P=0.001$ ) in six boroughs: Bacongo, Makélékélé, M'filou, Madibou, Talangaï and Djiri (Fig. 5a, Table 8) while BI values for Ae. aegypti were significantly higher compared to those for Ae. albopictus in Ouenzé and Poto-Poto (Wilcoxon rank sum test: $W=2, P=$
0.001). However, no significant difference was found in BI values of both species apart in Moungali (Wilcoxon rank sum test: $W=0, P>0.05$ ) (Fig. 5a, Table 8). Globally, the CI was $22.6 \%$ (95\% CI: $16.7-28.5 \%$ ) and $29.6 \%$ (95\% CI: 23.7-35.5\%) for Ae. aegypti and Ae. albopictus, respectively, with no significant difference (Chi-square test: $\chi^{2}=1.23, d f=2, P>0.05$ ) (Fig. 4a). However, the comparison of $\mathrm{CI}$ between both species according to the location of the boroughs (downtown vs suburb), showed that the CI was significantly higher in Ae. aegypti $32.4 \%$ (95\% CI: 26.1-38.7\%) than that of Ae. albopictus 29.1\% (95\% CI: $23.0-35.2 \%$ ) in downtown (Chi-square test: $X^{2}$ $=11.707, d f=1, P=0.0006)$. While in the suburb, the CI for Ae. albopictus 30\% (95\% CI: 24.3-35.7\%) was significantly higher (Chi-square test: $\chi^{2}=11.707, d f=1, P$ $=0.0006$ ) than for Ae. aegypti 14\% (95\% CI: 9.7-18.3\%) (Fig. 4b). The overall HI was $26.6 \%$ (95\% CI: 21.3-31.9\%) for Ae. aegypti and 33.3\% (95\% CI: 27.6-39.0\%) for Ae. albopictus respectively with no significant difference (Chi-square test: $\chi^{2}=1.23, d f=2, P>0.05$ ) (Fig. 4a). In contrast, $\mathrm{HI}$ values were significantly higher (Chi-square test: $\chi^{2}=7.493, d f=1, P=0.006$ ) for Ae. aegypti $31 \%$ (95\% CI: 23.3-38.6\%) than for Ae. albopictus 26.8\% (95\% 
Table 5 Factors influencing the presence of pupae of Aedes aegypti and Aedes albopictus in the larval habitat

\begin{tabular}{|c|c|c|c|c|c|}
\hline \multirow[t]{2}{*}{ Factor } & \multirow[t]{2}{*}{ Modality } & \multicolumn{2}{|l|}{ Ae. aegypti } & \multicolumn{2}{|l|}{ Ae. albopictus } \\
\hline & & OR & $95 \% \mathrm{Cl}$ & OR & $95 \% \mathrm{Cl}$ \\
\hline \multirow[t]{3}{*}{ Neighbourhoods location } & Downtown & Ref & Ref & Ref & Ref \\
\hline & Suburb & $0.07^{* * *}$ & $0.03-0.15$ & $1.93^{*}$ & $1.03-3.74$ \\
\hline & Rural & $0.08^{* * *}$ & $0.02-0.27$ & 1.03 & $0.33-2.95$ \\
\hline \multirow[t]{6}{*}{ Container types } & Axils of plants & na & na & Ref & Ref \\
\hline & Discarded tanks & na & na & $6.54 \times 10^{-9}$ & na- $6.34 \times 10^{203}$ \\
\hline & Flower-pots & na & na & $6.79 \times 10^{-9}$ & $\mathrm{na}-4.75 \times 10^{203}$ \\
\hline & Miscellaneous & na & na & $5.19 \times 10^{-9}$ & na- $-4.59 \times 10^{203}$ \\
\hline & Storage tanks & na & na & $2.01 \times 10^{-9}$ & $\mathrm{na}-1.47 \times 10^{203}$ \\
\hline & Used tyres & na & na & $5.97 \times 10^{-9}$ & na-4.18 $\times 10^{203}$ \\
\hline \multirow[t]{3}{*}{ Container colour } & Dark & Ref & Ref & na & na \\
\hline & Light & $0.25^{*}$ & $0.08-0.85$ & na & na \\
\hline & Transparent & $0.14^{* *}$ & $0.03-0.60$ & na & na \\
\hline \multirow[t]{4}{*}{ Container material } & Metal & Ref & Ref & Ref & Ref \\
\hline & Plastic & 1.84 & $0.76-4.74$ & 1.01 & $0.52-2.00$ \\
\hline & Rubber & $0.08^{* *}$ & $0.02-0.38$ & na & na \\
\hline & Miscellaneous & 1.35 & $0.29-5.52$ & 0.25 & $0.03-1.02$ \\
\hline \multirow[t]{3}{*}{ Water quality } & Clear & Ref & Ref & Ref & Ref \\
\hline & Turbid & $2.54^{*}$ & $1.24-5.19$ & $2.28^{*}$ & $1.23-4.16$ \\
\hline & Polluted & $3.95 \times 10^{-7}$ & na- $2.82 \times 10^{21}$ & $4.07 \times 10^{-7}$ & na- $-8.41 \times 10^{23}$ \\
\hline \multirow[t]{2}{*}{ Water source } & Tap & $0.38^{*}$ & $0.15-0.89$ & na & na \\
\hline & Rain & Ref & Ref & na & na \\
\hline \multirow[t]{2}{*}{ Presence of surrounding vegetation } & Yes & $5.81^{* * *}$ & $2.75-13.14$ & 1.98 & $1.08-3.77$ \\
\hline & No & Ref & Ref & Ref & Ref \\
\hline \multirow[t]{2}{*}{ Distance to nearest building } & $0-5 \mathrm{~m}$ & na & na & Ref & Ref \\
\hline & $5-10 m$ & na & na & 0.5 & $0.21-1.08$ \\
\hline
\end{tabular}

${ }^{*} P<0.05,{ }^{*} P<0.01,{ }^{* * *} P<0.0001$

Abbreviations: na, not applicable; $\mathrm{OR}$, odd ratio; $\mathrm{Cl}$, confidence interval; Ref, reference (the reference for each factor were randomly selected by the software) is a comparator group; distances in meters $(\mathrm{m})$

CI: 19.4-34\%) in downtown areas, whereas the opposite situation was observed between Ae. aegypti $21.6 \%$ (95\% CI: 14.3-28.8\%) and Ae. albopictus 40.8\% (95\% CI: 32.149.4\%) in suburb areas (Chi-square test: $\chi^{2}=7.493, d f=$ $1, P=0.006$ ) (Fig. 4b). The comparison of HI between both species according to the borough revealed that HIs were significantly higher (Chi-square test: $\chi^{2}=46.713, d f$ $=6, P<0.0001)$ for Ae. albopictus than for Ae. aegypti, in six boroughs (Bacongo, Makélékélé, Madibou, M'filou and Talangaï) whereas the reverse situation was observed in Ouenzé and Poto-Poto (Chi-square test: $\chi^{2}=46.713$, $d f=6, P<0.0001)$ and no significant difference was found between two species in Moungali and Djiri (Chisquare test: $\chi^{2}=0, d f=1, P>0.05$ ) (Fig. 5 b, Table 8 ).

The overall PI values were not significantly different (Chi-square test: $\chi^{2}=1.23, d f=2, P>0.05$ ) between $A e$. aegytpi 273.4\% (95\% CI: 148.5-398.3\%) and Ae. albopictus 228.8\% (95\% CI: 147.9-309.7\%) (Fig. 4a). Also, no significant difference (Chi-square test: $\chi^{2}=1.12, d f$ $=1, P>0.05$ ) was observed between PI values of $A e$. aegypti and Ae. albopictus in both downtown (417\%, 95\% CI: 195.2-640\%; 176\%, 95\% CI: 77.5-274.5\%) and the suburb (109.6\%, 95\% CI: 32-187.1\%; 288\%, 95\% CI: 156.6-419.4\%) locations, respectively (Fig. 4b). However, detailed analysis according to the borough showed that, PI values were significantly higher for Ae. albopictus than for Ae. aegypti (Chi-square test: $\chi^{2}=2248.2, d f$ $=8, P<0.0001$ ) respectively in five boroughs (Bacongo, Makélékélé, Madibou, M'filou and Talangaï), while these values were higher for Ae. aegypti compared to Ae. albopictus (Chi-square test: $\chi^{2}=2248.2, d f=8, P<0.0001$ ), in four boroughs (Moungali, Ouenzé, Poto-Poto and Djiri) (Fig. 6a, Table 8).

Globally, no significant difference (Wilcoxon rank sum test: $W=3, P>0.05$ ) was found between PPI values of 
Table 6 Factors influencing the number of pupae of Aedes aegypti and Aedes albopictus in Brazzaville

\begin{tabular}{|c|c|c|c|c|c|c|c|}
\hline \multirow[t]{2}{*}{ Factor } & \multirow[t]{2}{*}{ Modality } & \multicolumn{3}{|l|}{ Ae. aegypti } & \multicolumn{3}{|c|}{ Ae. albopictus } \\
\hline & & Estimate & SE & $z$-value & Estimate & SE & $z$-value \\
\hline \multirow[t]{3}{*}{ Neighbourhoods location } & Downtown & Ref & Ref & Ref & Ref & Ref & Ref \\
\hline & Suburb & $-25.81^{* * *}$ & 0.7024 & -36.74 & $1.38^{* *}$ & 0.43 & 3.25 \\
\hline & Rural & $3.55^{* *}$ & 1.19 & 2.970 & 0.52 & 0.73 & 0.72 \\
\hline \multirow[t]{6}{*}{ Container types } & Axils of plants & Ref & Ref & Ref & Ref & Ref & Ref \\
\hline & Discarded tanks & 170.22 & $6.71 \times 10^{7}$ & 0 & 0.92 & 3.41 & 0.27 \\
\hline & Flower-pots & 169.99 & $6.71 \times 10^{7}$ & 0 & 1.42 & 3.47 & 0.41 \\
\hline & Miscellaneous & 132.82 & $6.71 \times 10^{7}$ & 0 & -0.95 & 3.47 & -0.28 \\
\hline & Storage tanks & 148.40 & $6.71 \times 10^{7}$ & 0 & -1.04 & 3.43 & -0.30 \\
\hline & Used tyres & 175.28 & $6.71 \times 10^{7}$ & 0 & 1.61 & 3.54 & 0.45 \\
\hline \multirow[t]{3}{*}{ Container colour } & Dark & Ref & Ref & Ref & Ref & Ref & Ref \\
\hline & Light & $-11.27^{* * *}$ & 1.37 & -8.22 & 1.35 & 0.88 & 1.53 \\
\hline & Transparent & $-38.44^{* * *}$ & 1.58 & -24.28 & -0.14 & 0.99 & -0.14 \\
\hline \multirow[t]{4}{*}{ Container material } & Metal & Ref & Ref & Ref & na & na & na \\
\hline & Plastic & 15.01 & 0.89 & 16.83 & na & na & na \\
\hline & Rubber & na & na & na & na & na & na \\
\hline & Miscellaneous & 30.05 & 1.40 & 21.46 & na & na & na \\
\hline \multirow[t]{3}{*}{ Container volume } & $\operatorname{Low}(<5 \mathrm{I})$ & Ref & Ref & Ref & na & na & na \\
\hline & Medium (5-50 I) & $-13.92^{* * *}$ & 0.66 & -20.94 & na & na & na \\
\hline & High (> $50 \mathrm{l}$ ) & $23.68^{* * *}$ & 1.58 & 14.91 & na & na & na \\
\hline \multirow[t]{3}{*}{ Water volume } & $\operatorname{Low}(<5 \mathrm{I})$ & Ref & Ref & Ref & na & na & na \\
\hline & Medium (5-50 I) & $4.79 * * *$ & 0.80 & 5.96 & na & na & na \\
\hline & High (> $50 \mathrm{l})$ & $-84.72^{* * *}$ & 4.69 & -18.05 & na & na & na \\
\hline \multirow[t]{2}{*}{ Water source } & Tap & $4.06^{* * *}$ & 1.13 & 3.58 & na & na & na \\
\hline & Rain & Ref & Ref & Ref & na & na & na \\
\hline \multirow[t]{3}{*}{ Water quality } & Clear & Ref & Ref & Ref & Ref & Ref & Ref \\
\hline & Turbid & -0.97 & 0.73 & -1.325 & $1.98^{* * *}$ & 0.44 & 4.37 \\
\hline & Polluted & 3.24 & 2.19 & 1.48 & -30.34 & $7.66 \times 10^{7}$ & 0 \\
\hline \multirow[t]{3}{*}{ Shade } & None & $-9.75^{* * *}$ & 0.65 & -14.99 & $-1.12^{* *}$ & 0.39 & -2.82 \\
\hline & Partial & -10.26 & 1.06 & -9.65 & -0.7451 & 0.59 & -1.25 \\
\hline & Full & Ref & Ref & Ref & Ref & Ref & Ref \\
\hline \multirow[t]{2}{*}{ Plant residues } & Yes & $9.33^{* * *}$ & 0.71 & 13.10 & na & na & na \\
\hline & No & Ref & Ref & Ref & na & na & na \\
\hline \multirow[t]{2}{*}{ Presence of surrounding vegetation } & Yes & $15.56^{* * *}$ & 0.96 & 16.14 & $1.47^{* * *}$ & 0.4212 & 3.49 \\
\hline & No & Ref & Ref & Ref & Ref & Ref & Ref \\
\hline \multirow[t]{3}{*}{ Distance to nearest plant } & $0-5 \mathrm{~m}$ & $19.56^{* * *}$ & 1.04 & 18.71 & na & na & na \\
\hline & $5-10 \mathrm{~m}$ & $18.94^{* * *}$ & 2.09 & 9.02 & na & na & na \\
\hline & $>10 \mathrm{~m}$ & Ref & Ref & Ref & na & na & na \\
\hline \multirow[t]{2}{*}{ Distance to nearest building } & $0-5 \mathrm{~m}$ & Ref & Ref & Ref & Ref & Ref & Ref \\
\hline & $5-10 m$ & $5.69^{* * *}$ & 0.83 & 6.77 & $-1.69^{* *}$ & 0.57 & -3.23 \\
\hline \multirow[t]{2}{*}{ Distance to ground } & $0-1 \mathrm{~m}$ & Ref & Ref & Ref & na & na & na \\
\hline & $1-3 m$ & $4.94^{*}$ & 2.38 & 2.07 & na & na & na \\
\hline
\end{tabular}

${ }^{*} P<0.05,{ }^{* *} P<0.01$, **** $P<0.0001$

Abbreviations: na, not applicable; $\mathrm{Cl}$, confidence interval; Ref, reference (the reference for each factor were randomly selected by the software) is a comparator group; $\mathrm{SE}$, standard error; distance in meters $(\mathrm{m})$, volume in litres (I)

Ae. aegypti $23.2 \%$ (95\% CI: 20.4-26.0\%) compared to Ae. albopictus 19.5\% (95\% CI: 16.6-22.2\%) (Fig. 4a). Similarly, no significant difference (Wilcoxon rank sum test: $W=2$,
$P>0.05)$ was observed between PPI values of Ae. aegypti and Ae. albopictus in both downtown $(47.2 \%, 95 \% \mathrm{CI}$ : 41.7-52.7\%; 9.8\%, 95\% CI: 6.7-13\%) and suburb (7.9\%, 

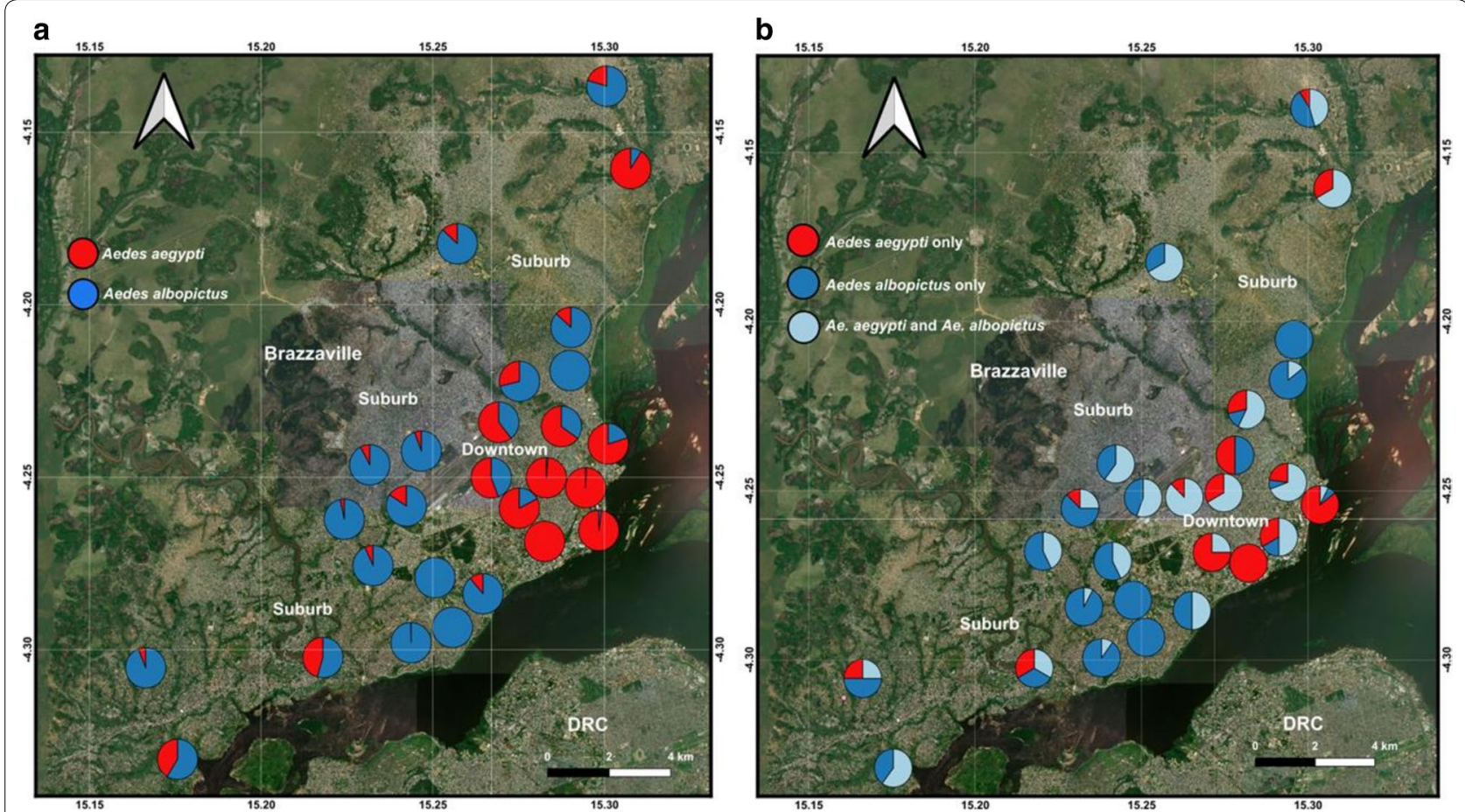

Fig. 3 Geographical distribution of Ae. aegypti and Ae. albopictus in Brazzaville boroughs in 2017. a Spatial distribution and abundance of Ae. aegypti and Ae. albopictus according to the neighbourhoods. b Spatial distribution of positive larval habitats, and their occupancy (Ae. aegypti only; Ae. albopictus only; both Ae. aegypti; and Ae. albopictus) according to the neighbourhoods

Table 7 Abundance of Aedes aegypti and Aedes albopictus species according to the borough

\begin{tabular}{|c|c|c|c|c|c|c|}
\hline \multirow[t]{2}{*}{ Location } & \multirow[t]{2}{*}{ Borough } & \multicolumn{2}{|c|}{ Ae. aegypti } & \multicolumn{2}{|c|}{ Ae. albopictus } & \multirow[t]{2}{*}{$P$-value } \\
\hline & & $n$ & Mean \pm SE & $n$ & Mean \pm SE & \\
\hline \multirow[t]{3}{*}{ Downtown } & Moungali & 341 & $8.12 \pm 3.64$ & 320 & $7.62 \pm 2.15$ & 0.513 \\
\hline & Ouenzé & 805 & $20.64 \pm 7.12$ & 87 & $2.23 \pm 0.83$ & $<0.001$ \\
\hline & Poto-Poto & 532 & $7.82 \pm 2.01$ & 31 & $0.46 \pm 0.22$ & $<0.001$ \\
\hline \multirow[t]{6}{*}{ Suburb } & Bacongo & 3 & $0.09 \pm 0.07$ & 282 & $8.54 \pm 3.42$ & $<0.001$ \\
\hline & Djiri & 143 & $2.51 \pm 1.16$ & 223 & $3.91 \pm 1.39$ & 0.359 \\
\hline & Madibou & 45 & $0.78 \pm 0.45$ & 91 & $1.57 \pm 0.56$ & 0.3717 \\
\hline & Makélékélé & 34 & $0.67 \pm 0.35$ & 330 & $6.47 \pm 1.55$ & $<0.001$ \\
\hline & M'filou & 10 & $0.14 \pm 0.05$ & 200 & $2.86 \pm 0.89$ & $<0.001$ \\
\hline & Talangaï & 80 & $2.16 \pm 1.07$ & 196 & $5.29 \pm 2.39$ & 0.058 \\
\hline
\end{tabular}

Abbreviations: $n$, number; $\mathrm{SE}$, standard error; $P$-value, level of significance between mean numbers of Ae. aegypti and Ae. albopictus according to the boroughs. Statistically significant $P$-values are indicated in italic

95\% CI: 5.5-10.2\%; 25.7\%, 95\% CI: 22.0-29.4\%) (Fig. 4b). Nevertheless, analysis according to the boroughs showed that PPI values were higher for Ae. albopictus compared to Ae. aegypti (Wilcoxon rank sum test: $W=0, P$ $=0.002)$ in Bacongo, Makélékélé and M'filou, while PPI values were higher for Ae. aegypi compared to Ae. albopictus respectively in Ouenzé, Poto-Poto, (Wilcoxon rank sum test: $W=0, P=0.002)$ and no significant difference was found between both species in Moungali, Madibou, Talangaï and Djiri (Wilcoxon rank sum test: $W=5, P>$ 0.05) (Fig. 6b, Table 8).

\section{Discussion}

This detailed study presents a comparative analysis of the ecological adaptation of the two major arbovirus vectors Ae. aegypti and Ae. albopictus, in Brazzaville, the major 

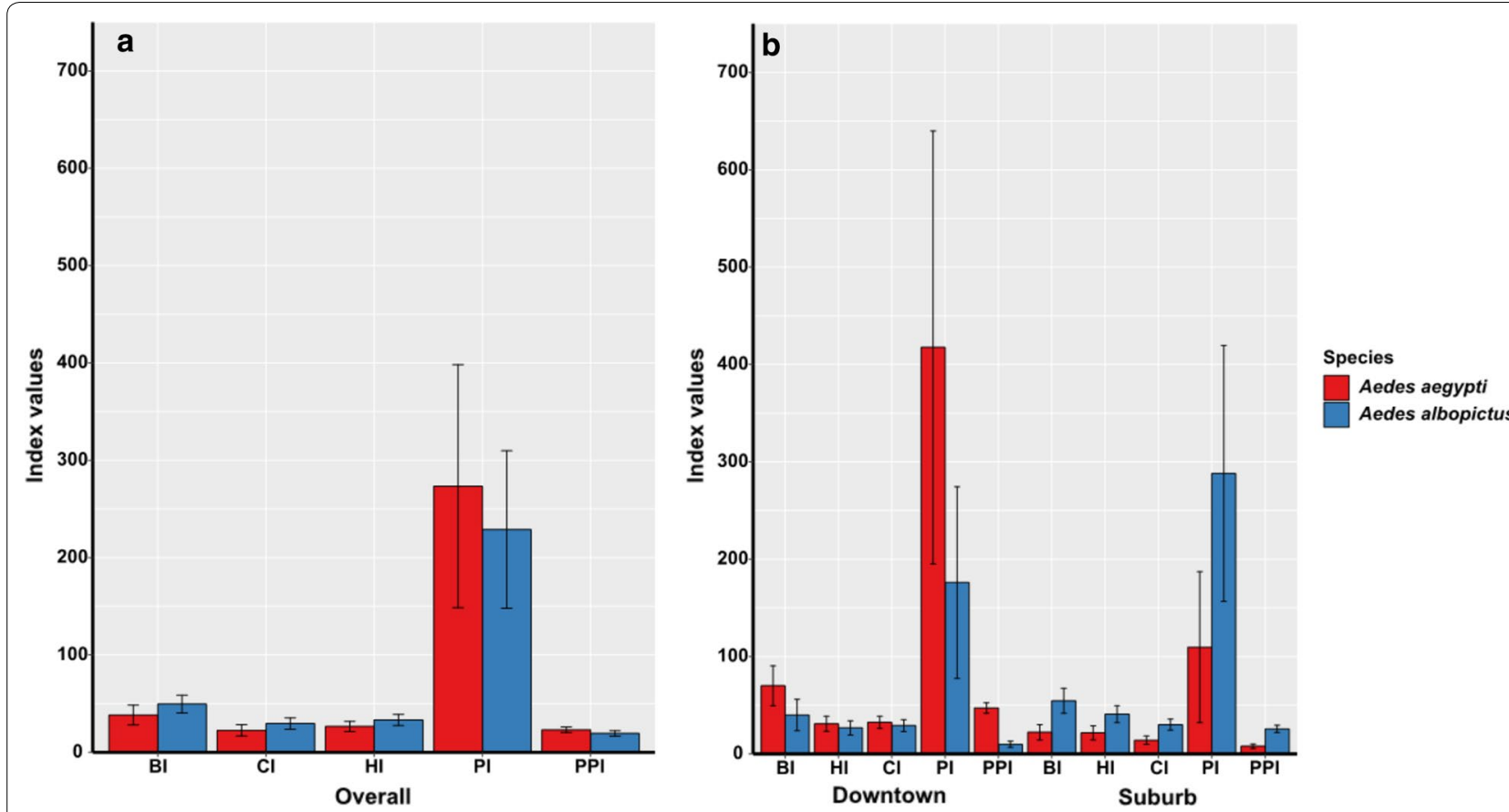

Fig. 4 Level of infestation of Ae. aegypti and Ae. albopictus in Brazzaville in 2017. a Overall Stegomyia and pupae indices of Ae. aegypti and Ae. albopictus in Brazzaville. $\mathbf{b}$ Infestation indices of Ae. aegypti and Ae. albopictus according to the location of the borough. Abbreviations: Bl, Breteau index (and 95\% confidence interval); Cl, container index (and 95\% confidence interval); $\mathrm{HI}$, house index (and 95\% confidence interval); $\mathrm{Pl}$, pupae index (and 95\% confidence interval); PPI, pupae per person index (and 95\% confidence interval)
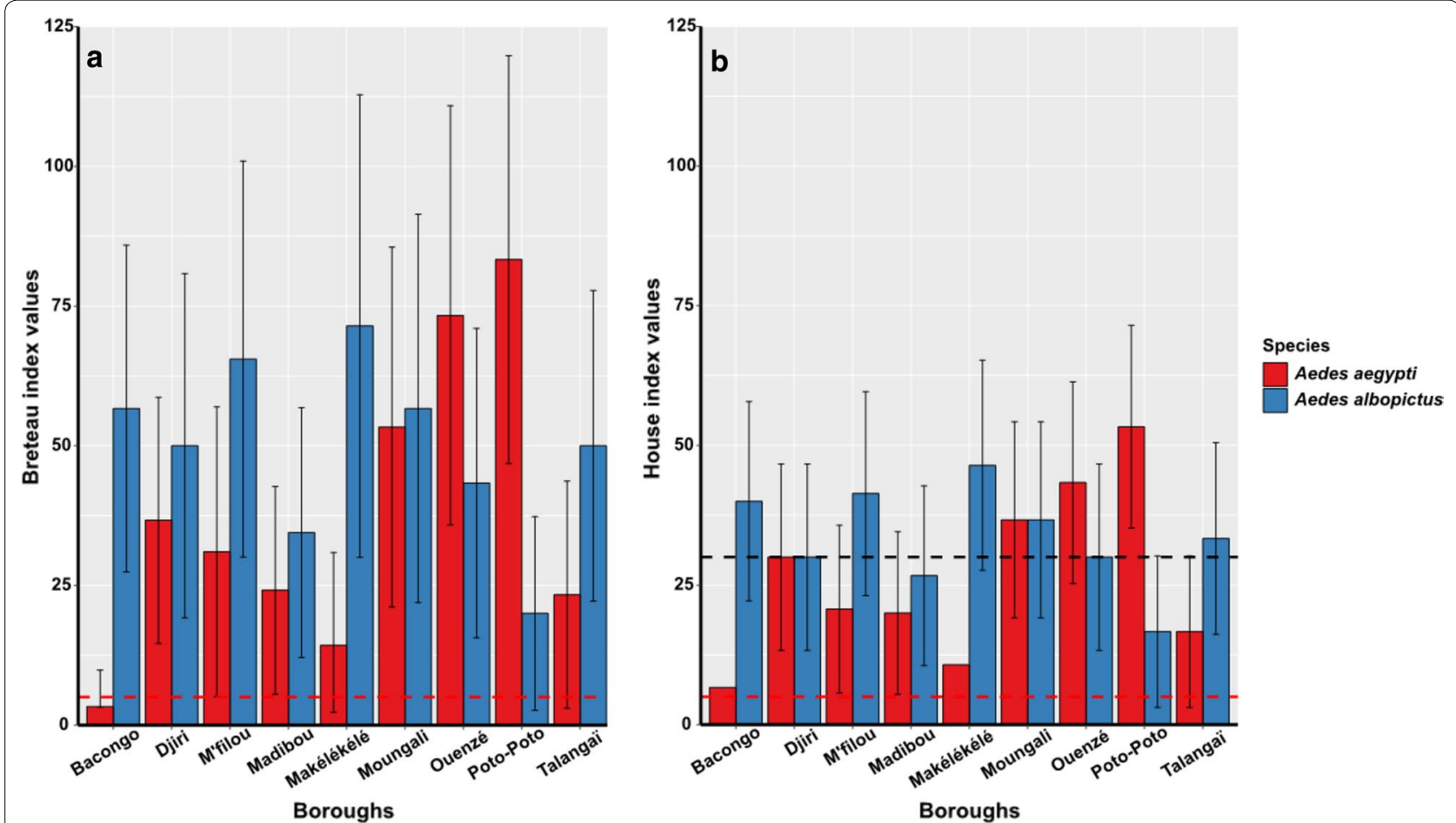

Fig. 5 Infestation indices of Aedes spp. according to each borough. a Bl, Breteau index (and 95\% confidence interval). b HI, house index (and 95\% confidence interval); black and red dashed line, represent the yellow fever and dengue epidemic threshold, respectively, defined by the WHO and $\mathrm{PAHO}$ 

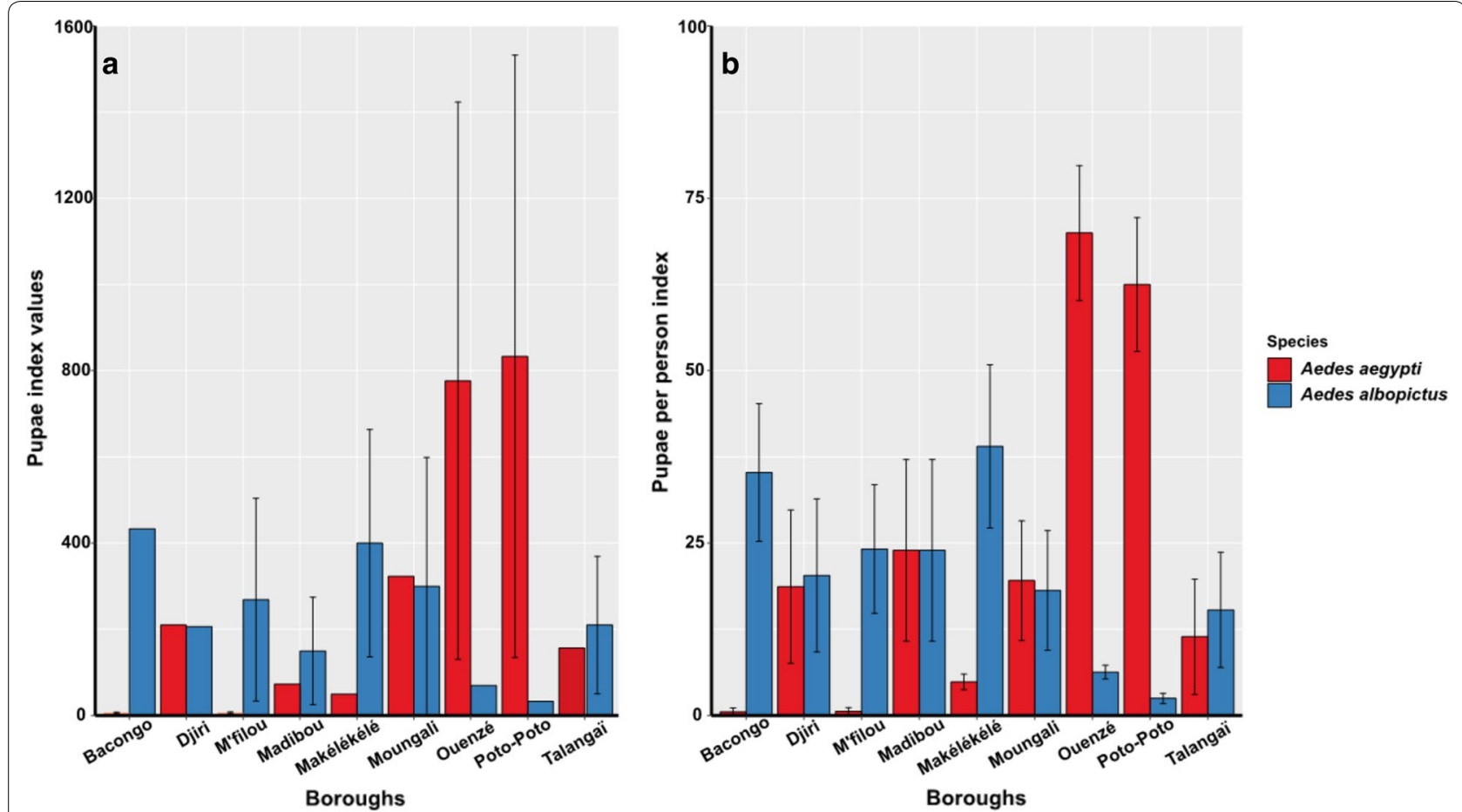

Fig. 6 Pupae based indices of Ae. aegypti and Ae. albopictus according to each borough. a Pl, pupae index (and 95\% confidence interval). b PPI, pupae per person index (and 95\% confidence interval)

Table 8 Infestation indices of Aedes species according to the boroughs

\begin{tabular}{|c|c|c|c|c|c|c|c|c|}
\hline \multirow[t]{2}{*}{ Borough } & \multicolumn{4}{|l|}{ Ae. aegypti } & \multicolumn{4}{|l|}{ Ae. albopictus } \\
\hline & $\mathrm{BI}(95 \% \mathrm{Cl})$ & HI $(95 \%$ Cl) & $\mathrm{PI}(95 \% \mathrm{Cl})$ & PPI (95\% Cl) & Bl (95\% Cl) & $\mathrm{HI}(95 \% \mathrm{Cl})$ & PI (95\% CI) & PPI (95\% Cl) \\
\hline Bacongo & 3.33 (3.19-9.86) & $\begin{array}{l}6.67(2.41- \\
15.74)\end{array}$ & $6.67(5.35-8)$ & $0.54(0-1.08)$ & $\begin{array}{l}56.67(27.43- \\
85.91)\end{array}$ & $\begin{array}{c}40(22.17- \\
57.83)\end{array}$ & $\begin{array}{l}433.33(29.38- \\
896.04)\end{array}$ & $\begin{array}{l}35.23(25.5- \\
45.21)\end{array}$ \\
\hline Djiri & $\begin{array}{l}36.67(14.66- \\
58.68)\end{array}$ & $\begin{array}{c}30(13.32- \\
46.68)\end{array}$ & $210(5.8-425.8)$ & $\begin{array}{l}18.69(7.59- \\
29.79)\end{array}$ & $\begin{array}{c}50(19.18- \\
80.81)\end{array}$ & $\begin{array}{c}30(13.32- \\
46.68)\end{array}$ & $\begin{array}{l}206.67(14.11- \\
427.44)\end{array}$ & $\begin{array}{l}20.33(9.23- \\
31.43)\end{array}$ \\
\hline M'filou & $\begin{array}{l}31.03(5.10- \\
56.95)\end{array}$ & $\begin{array}{l}20.69(5.68- \\
35.69)\end{array}$ & $6.9(5.52-8.27)$ & $0.62(0.09-1.15)$ & $\begin{array}{l}65.52(30.08- \\
100.96)\end{array}$ & $\begin{array}{l}41.38(23.14- \\
59.62)\end{array}$ & $\begin{array}{l}268.96(33.87- \\
504.05)\end{array}$ & $\begin{array}{l}24.15(14.83- \\
33.47)\end{array}$ \\
\hline Madibou & $\begin{array}{l}24.14(5.54- \\
42.74)\end{array}$ & $20(5.44-34.56)$ & $\begin{array}{l}73.33(26.97- \\
173.64)\end{array}$ & $\begin{array}{l}23.97(10.81- \\
37.13)\end{array}$ & $\begin{array}{l}34.48(12.14- \\
56.82)\end{array}$ & $\begin{array}{l}26.67(10.57- \\
42.76)\end{array}$ & $\begin{array}{l}150(25.06- \\
274.93)\end{array}$ & $\begin{array}{l}23.97(10.81- \\
37.13)\end{array}$ \\
\hline Makélékélé & $\begin{array}{l}14.29(2.31- \\
30.89)\end{array}$ & $\begin{array}{l}10.71(0.95- \\
22.38)\end{array}$ & $50(18.7-118.7)$ & $4.88(3.76-5.99)$ & $\begin{array}{l}71.43(30.04- \\
112.82)\end{array}$ & $\begin{array}{l}46.43(27.62- \\
65.24)\end{array}$ & $\begin{array}{l}400(136.34- \\
663.65)\end{array}$ & $\begin{array}{l}39.02(27.20- \\
50.85)\end{array}$ \\
\hline Moungali & $\begin{array}{l}53.33(21.14- \\
85.52)\end{array}$ & $\begin{array}{l}36.67(19.13- \\
54.20)\end{array}$ & $\begin{array}{l}323.33(66.82- \\
713.49)\end{array}$ & $\begin{array}{l}19.57(10.89- \\
28.23)\end{array}$ & $\begin{array}{l}56.67(21.91- \\
91.43)\end{array}$ & $\begin{array}{l}36.67(19.13- \\
54.20)\end{array}$ & $\begin{array}{c}300(1.49- \\
598.51)\end{array}$ & $\begin{array}{l}18.14(9.48- \\
26.81)\end{array}$ \\
\hline Ouenzé & $\begin{array}{l}73.33(35.82- \\
110.84)\end{array}$ & $\begin{array}{l}43.33(25.30- \\
61.37)\end{array}$ & $\begin{array}{l}776.67(130.31- \\
1423.02)\end{array}$ & $\begin{array}{l}69.97(60.18- \\
79.76)\end{array}$ & $\begin{array}{l}43.33(15.64- \\
\quad 71.02)\end{array}$ & $\begin{array}{c}30(13.32- \\
46.68)\end{array}$ & $\begin{array}{l}70(22.15- \\
\quad 162.15)\end{array}$ & $6.31(5.33-7.29)$ \\
\hline Poto-Poto & $\begin{array}{l}83.33(46.83- \\
119.83)\end{array}$ & $\begin{array}{l}53.33(35.17- \\
71.49)\end{array}$ & $\begin{array}{l}833.33(134.67- \\
1532)\end{array}$ & $\begin{array}{l}62.5(52.79- \\
72.21)\end{array}$ & $20(2.67-37.33)$ & $\begin{array}{l}16.67(3.10- \\
30.23)\end{array}$ & $\begin{array}{l}33.33(7.99- \\
74.65)\end{array}$ & $2.5(1.75-3.25)$ \\
\hline Talangaï & $23.33(3-43.67)$ & $\begin{array}{l}16.67(3.10- \\
30.23)\end{array}$ & $\begin{array}{l}156.67(58.59- \\
371.92)\end{array}$ & $\begin{array}{l}11.43(3.09- \\
19.79)\end{array}$ & $50(22.2-77.8)$ & $\begin{array}{l}33.33(16.17- \\
50.49)\end{array}$ & $\begin{array}{c}210(50.70- \\
369.30)\end{array}$ & $\begin{array}{l}15.33(6.98- \\
23.68)\end{array}$ \\
\hline
\end{tabular}

Abbreviations: $\mathrm{BI}$, Breteau index; $\mathrm{HI}$, house index; $\mathrm{PI}$, pupae index; $\mathrm{PPI}$, pupae per person index; $\mathrm{Cl}$, confidence interval

city of the Republic of the Congo with a special emphasis on their container preferences, level of infestation, and parameters influencing their distribution and abundance.
Our analysis revealed that both Ae aegypti and Ae. albopictus co-exists in all surveyed boroughs in Brazzaville. The co-occurrence of Ae. aegypti and Ae. albopictus 
across the Brazzaville city suggests that the environmental factors which prevail in the city are favourable for the development of both species. The presence of $A e$. albopictus in the Republic of the Congo was confirmed in 2011 during the chikungunya outbreak in Brazzaville [24] suggesting its recent introduction, while Ae. aegypti was documented in the country since 1970 [48]. Overall, the prevalence of Ae. aegypti in the city of Brazzaville was higher than that of Ae. albopictus. This is in accordance with the previous data collected across Brazzaville in May 2017 corresponding to the early rainy season indicating that Ae. aegypti was the dominant Aedes species in the city [25]. However, the comparative analysis of the prevalence of both Aedes species across the city of Brazzaville indicates that Ae. aegypti is most prevalent in downtown while Ae. albopictus is most prevalent in suburban and rural areas. Indeed, the dominance of Ae. albopictus in neighbourhoods located in periurban areas in Brazzaville has been previously reported [38]. These observations are in accordance to previous studies in Central Africa which demonstrated that in sympatric areas, Ae. aegypti is most prevalent in neighbourhoods located in downtown with a higher building density, while Ae. albopictus is found more frequently in periurban areas surrounded by vegetation $[27,29,30]$. Importantly, seasonality can affect the pattern of abundance of both species as demonstrated previously [27,49], perhaps due to the difference in the tolerance of desiccation of the eggs of both species [50]. However, previous data collected in Central Africa suggest that this variation depends to the difference of time between the rainy season and the dry season among locations [30].

Larvae of both Ae. aegypti and Ae. albopictus were found colonizing all container types surveyed across the city. However, peridomestic containers, especially discarded tanks were the most prevalent and the most productive containers for both species. The preference of both species to colonize discarded tanks is in agreement with previous studies in Cameroun [29] and in Central African Republic [27]. These observations are contrary to those generally observed in other regions of the world, particularly in Asia, where Ae. aegypti larvae breed commonly in domestic containers such as water storage tanks $[44,51,52]$. Unplanned urbanization and lack of waste management can explain the proliferation of peridomestic containers such as discarded tanks and used tyres in Brazzaville. This can explain why Ae. aegypti was found associated with turbid water in this study. The prevalence of water storage containers (27\%) observed in Brazzaville suggests a lack of running water in human-dwellings that would promote the storage of water. This prevalence is high compared to that reported in other cities from
Central Africa such as Yaoundé and Douala in Cameroon [29].

No significant difference was observed in pupae abundance between the two species according to the container types, except in used tyres for which the abundance of Ae. albopictus pupae was higher than the abundance of Ae. aegypti pupae suggesting that Ae. albopictus infests more used tyres compared to Ae. aegypti. Indeed, the invasion of Ae. albopictus from Asia to other continents was suggested to be driven by the commercialization of used tyres [22,53]. Several container-related factors were impacting the presence and or the abundance of Aedes immature stages notably the turbidity of water which indicates that the presence of organic matter in the water which can supply food resources. In addition, turbidity of water can also serve to hide aquatic stages of Aedes from predators as suggested previously [27, 54]. The presence of the vegetation around the container provides shade which reduces the water temperature in the Aedes larval habitat $[27,55]$. It was demonstrated that the variation of water volume inside the container, can modulate attractiveness to oviposition, space availability and food resources accessibility $[54,56,57]$. The coexistence of the invasive species Ae. albopictus and the native species Ae. aegypti in the same ecological niche, implies interspecific competition for resources, which leads to segregation of habitats according to macro-environmental variations such as urban environmental gradients, as shown previously $[55,58]$ or the decrease of the abundance of the native species $[28,59,60]$.

The level of infestation of both vector species, was assessed by calculating Stegomiya indices. Traditional Stegomiya indices, HI, BI and CI are commonly used to measure the success of vector control strategy to understand the vector ecology. However, these indices are considered by some authors as a poor predictors of epidemiological risk because they are generally not correlated with disease incidence or outbreak [61]. Based on that, Focks \& Chadee [62] suggested that pupae based indices such as PI and PPI, which are more epidemiologically relevant indices, could be better predictors for arboviruses transmission; because of their correlation between total pupal densities and adult densities.

Traditional Stegomyia indices (BI, CI and HI) and pupal indices (PI, PPI) in our study were relatively high for both species across the city of Brazzaville. Although no significant differences were reported between the index values of the two species at the city scale, all index values significantly varied according to the boroughs and the environment (downtown $v s$ suburb). It would be interesting to highlight that this pattern can change according to the season, as mentioned in a previous study in two neighbourhoods of Brazzaville which reported a decrease 
of Stegomyia indices in the dry season compared to the rainy season [38]. The overall $\mathrm{BI}(38.4 \%)$ and $\mathrm{HI}(26.5 \%)$ estimated in Brazzaville for Ae. aegypti were higher compare to those estimated in previous studies in other cities from Central Africa such as Yaoundé in Cameroon (BI: 10.1\%, HI: 9.0\%) [29] and Bangui in the Central African Republic irrespective to the season (early wet season: the BI and HI were $14.4 \%$ and $9.03 \%$, respectively; late wet season: the BI and HI were $16.5 \%$ and $21.8 \%$, respectively) [27]. Similar observations were reported for Ae. albopictus [27]. In addition, index values for both species estimated, were high compared to the reference epidemic thresholds of transmission risk established for yellow fever [42] and for dengue [43]. The high infestation indices of both species suggest a risk for large outbreaks of arbovirus infections such as dengue, yellow fever, Zika, and chikungunya in Brazzaville. Indeed, two large chikungunya outbreaks were reported in the Republic of the Congo during the past decade [13, 34]. During these outbreaks, chikungunya virus was detected in both Ae. albopictus and Ae. aegypti in 2011 [24], while Ae. albopictus was suspected as the main vector during the 2019 outbreak [34]. In addition, it was demonstrated that both Ae. aegypti and Ae. albopictus from Brazzaville, are able to ensure yellow fever virus [35], dengue virus [37], Zika virus [36] transmission. To clearly establish the epidemiological importance of each Aedes species in the Republic of the Congo, additional experiments including feeding behaviour patterns, covering additional locations, and spanning several seasons are needed.

\section{Conclusions}

Our study revealed high infestation rates of Ae. aegypti and Ae. albopictus across Brazzaville, the major city of the Republic of the Congo, implying a strong potential for human arbovirus infection. Findings generated on the typology, geographical distribution, and productivity of larval development sites of both Aedes species could be useful to implement vector control programmes, including management of larval sources by establishing a targeted discarding of most of the productive larval habitats.

\section{Supplementary information}

Supplementary information accompanies this paper at https://doi. org/10.1186/s13071-020-04374-x.

Additional file 1: Table S1. Input files used for modelling binary logistic regression and a negative binomial regression model.

\section{Abbreviations}

AIC: Akaike's information criterion; BI: Breteau index; Cl: container index; GPS: global positioning system; HI: house index; PAHO: Pan American Health
Organization; PI: pupae index; PPI: pupae-per-person index; SD: standard deviation; SE: standard error; WHO: World Health Organization.

\section{Acknowledgements}

We would like to thank the population of Brazzaville city for their collaboration during the field work. We would also like to thank Dr Wilson Toussile from Ecole Nationale Supérieure Polytechnique University of Yaoundé/Cameroon; and Mr Mouanda Martinez from CIESPAC-OCEAC, Brazzaville/Republic of the Congo; for their support.

\section{Authors' contributions}

TAWB, BK and CSW designed the study. TAWB and BK participated in field surveys with support from AL. TAWB extracted the data and carried out the data analysis with support from BK. TAWB, BK, AL and CSW wrote and reviewed the article. All authors read and approved the final manuscript.

\section{Funding}

This study was supported by the Wellcome Trust Training Fellowship in Public Health and Tropical Medicine (204862/Z/16/Z) awarded to BK. The funders had no role in study design, data collection or analysis, decision to publish or preparation of the manuscript.

\section{Availability of data and materials}

All data generated or analysed during this study are included in this published article and its additional file.

\section{Ethics approval and consent to participate}

No specific authorization was requested to conduct this study; however, an oral consent form was obtained from the head or representative of each household owner prior to the survey.

\section{Consent for publication}

Not applicable.

\section{Competing interests}

The authors declare that they have no competing interests.

\section{Author details}

${ }^{1}$ Centre for Research in Infectious Diseases (CRID), P.O. Box 13591, Yaoundé, Cameroon. ${ }^{2}$ Laboratory of Biodiversity and Animal Ecology, Department of Animal Biology and Physiology, Faculty of Sciences and Technology, Marien Ngouabi University, P.O. Box 69, Brazzaville, Congo. ${ }^{3}$ Liverpool School of Tropical Medicine, Pembroke Place, Liverpool L3 5QA, UK.

Received: 13 May 2020 Accepted: 20 September 2020

Published online: 25 September 2020

\section{References}

1. Bhatt S, Gething PW, Brady OJ, Messina JP, Farlow AW, Moyes CL, et al. The global distribution and burden of dengue. Nature. 2013;496:504.

2. World Health Organisation. Zika situation report: neurological syndrome and congenital anomalies. 2016. Geneva: World Health Organisation; 2016

3. Cauchemez S, Besnard M, Bompard P, Dub T, Guillemette-Artur P, Eyrolle-Guignot D, et al. Association between Zika virus and microcephaly in French Polynesia, 2013-15: a retrospective study. Lancet. 2016;387:2125-32

4. Cao-Lormeau VM, Blake A, Mons S, Lastère S, Roche C, Vanhomwegen J, et al. Guillain-Barré syndrome outbreak associated with Zika virus infection in French Polynesia: a case-control study. Lancet. 2016;387:1531-9.

5. Mécharles S, Herrmann C, Poullain P, Tran TH, Deschamps N, Mathon G, et al. Acute myelitis due to Zika virus infection. Lancet. 2016;387:1481.

6. Garske T, Van Kerkhove MD, Yactayo S, Ronveaux O, Lewis RF, Staples JE, et al. Yellow fever in Africa: estimating the burden of disease and impact of mass vaccination from outbreak and serological data. PLoS Med. 2014;11:e1001638.

7. Peyrefitte CN, Rousset D, Pastorino BA, Pouillot R, Bessaud M, Tock F, et al. Chikungunya virus, Cameroon, 2006. Emerg Infect Dis. 2007;13:768. 
8. Peyrefitte CN, Bessaud M, Pastorino BA, Gravier P, Plumet S, Merle OL, et al. Circulation of chikungunya virus in Gabon, 2006-2007. J Med Virol. 2008;80:430-3.

9. Leroy EM, Nkoghe D, Ollomo B, Nze-Nkogue C, Becquart P, Grard G, et al. Concurrent chikungunya and dengue virus infections during simultaneous outbreaks, Gabon, 2007. Emerg Infect Dis. 2009;15:591.

10. Franco L, Di Caro A, Carletti F, Vapalahti O, Renaudat C, Zeller H, et al. Recent expansion of dengue virus serotype 3 in West Africa. Euro Surveill. 2010:15:19490.

11. Paupy C, Ollomo B, Kamgang B, Moutailler S, Rousset D, Demanou M, et al. Comparative role of Aedes albopictus and Aedes aegypti in the emergence of dengue and chikungunya in central Africa. Vector Borne Zoo Dis. 2010;10:259-66.

12. Schwartz E, Meltzer E, Mendelson M, Tooke A, Steiner F, Gautret $P$, et al. Detection on four continents of dengue fever cases related to an ongoing outbreak in Luanda, Angola, March to May 2013. Euro Surveill. 2013;18:20488.

13. Moyen N, Thiberville SD, Pastorino B, Nougairede A, Thirion L, Mombouli $\mathrm{JV}$, et al. First reported chikungunya fever outbreak in the republic of Congo, 2011. PLoS ONE. 2014;9:e115938.

14. Tarnagda Z, Cisse A, Bicaba BW, Diagbouga S, Sagna T, Ilboudo AK, et al. Dengue fever in Burkina Faso, 2016. Emerg Infect Dis. 2018;24:170

15. Christophers SR. Aedes aegypti: the yellow fever mosquito. London: CUP Archive; 1960

16. Mattingly P. Genetical aspects of the Aëdes aegypti problem: I._- - taxonomy and bionomics. Ann Trop Med Parasitol. 1957;51:392-408.

17. Paupy C, Delatte H, Bagny L, Corbel V, Fontenille D. Aedes albopictus, an arbovirus vector: from the darkness to the light. Microbes Infect. 2009;11:1177-85.

18. Paupy C, Brengues C, Kamgang B, Hervé JP, Fontenille D, Simard F. Gene flow between domestic and sylvan populations of Aedes aegypti (Diptera: Culicidae) in North Cameroon. J Med Entomol. 2014;45:391-400.

19. Morrison AC, Zielinski-Gutierrez E, Scott TW, Rosenberg R. Defining challenges and proposing solutions for control of the virus vector Aedes aegypti. PLoS Med. 2008;5:e68.

20. Gloria-Soria A, Ayala D, Bheecarry A, Calderon-Arguedas O, Chadee DD, Chiappero M, et al. Global genetic diversity of Aedes aegypti. Mol Ecol. 2016:25:5377-95.

21. Kotsakiozi P, Evans BR, Gloria-Soria A, Kamgang B, Mayanja M, Lutwama J, et al. Population structure of a vector of human diseases: Aedes aegypti in its ancestral range, Africa. Ecol Evol. 2018:8:7835-48.

22. Gratz N. Critical review of the vector status of Aedes albopictus. Med Vet Entomol. 2004;18:215-27.

23. Fontenille D, Toto JC. Aedes (Stegomyia) albopictus (Skuse), a potential new dengue vector in southern Cameroon. Emerg Infect Dis. 2001;7:1066.

24. Mombouli JV, Bitsindou P, Elion DO, Grolla A, Feldmann H, Niama FR, et al. Chikungunya virus infection, Brazzaville, Republic of Congo, 2011. Emerg Infect Dis. 2013;19:1542

25. Kamgang B, Wilson-Bahun TA, Irving H, Kusimo MO, Lenga A, Wondji CS. Geographical distribution of Aedes aegypti and Aedes albopictus (Diptera: Culicidae) and genetic diversity of invading population of Ae. albopictus in the Republic of the Congo. Wellcome Open Res. 2018:3:79.

26. Simard F, Nchoutpouen E, Toto JC, Fontenille D. Geographic distribution and breeding site preference of Aedes albopictus and Aedes aegypti (Diptera: Culicidae) in Cameroon, Central Africa. J Med Entomol. 2005:42:726-31.

27. Kamgang B, Ngoagouni C, Manirakiza A, Nakouné E, Paupy C, Kazanji M. Temporal patterns of abundance of Aedes aegypti and Aedes albopictus (Diptera: Culicidae) and mitochondrial DNA analysis of Ae. albopictus in the Central African Republic. PLoS Negl Trop Dis. 2013;7:e2590.

28. Tedjou AN, Kamgang B, Yougang AP, Njiokou F, Wondji CS. Update on the geographical distribution and prevalence of Aedes aegypti and Aedes albopictus (Diptera: Culicidae), two major arbovirus vectors in Cameroon. PLoS Negl Trop Dis. 2019;13:e0007137.

29. Kamgang B, Happi JY, Boisier P, Njiokou F, Herve JP, Simard F, et al. Geographic and ecological distribution of the dengue and chikungunya virus vectors Aedes aegypti and Aedes albopictus in three major Cameroonian towns. Med Vet Entomol. 2010;24:132-41.

30. Kamgang B, Yougang AP, Tchoupo M, Riveron JM, Wondji C. Temporal distribution and insecticide resistance profile of two major arbovirus vectors Aedes aegypti and Aedes albopictus in Yaoundé, the capital city of Cameroon. Parasit Vectors. 2017;10:469.

31. Weetman D, Kamgang B, Badolo A, Moyes C, Shearer F, Coulibaly M, et al. Aedes mosquitoes and Aedes-borne arboviruses in Africa: current and future threats. Int J Environ Res Public Health. 2018;15:220.

32. Ngoagouni C, Kamgang B, Nakoune E, Paupy C, Kazanji M. Invasion of Aedes albopictus (Diptera: Culicidae) into central Africa: what consequences for emerging diseases? Parasit Vectors. 2015;8:191.

33. Pagès F, Peyrefitte CN, Mve MT, Jarjaval F, Brisse S, Iteman I, et al. Aedes albopictus mosquito: the main vector of the 2007 chikungunya outbreak in Gabon. PLoS ONE. 2009;4:e4691.

34. Fritz M, Taty RT, Portella C, Guimbi C, Mankou M, Leroy EM, et al. Re-emergence of chikungunya in the Republic of the Congo in 2019 associated with a possible vector-host switch. Int J Infect Dis. 2019;84:99-101.

35. Kamgang B, Vazeille M, Yougang AP, Tedjou AN, Wilson-Bahun TA, Mousson L, et al. Potential of Aedes albopictus and Aedes aegypti (Diptera: Culicidae) to transmit yellow fever virus in urban areas in Central Africa. Emerg Microbes Infect. 2019;8:1636-41.

36. Kamgang B, Vazeille M, Tedjou A, Yougang AP, Wilson-Bahun TA, Mousson $\mathrm{L}$, et al. Different populations of Aedes aegypti and Aedes albopictus (Diptera: Culicidae) from Central Africa are susceptible to Zika virus infection. PLoS Negl Trop Dis. 2020;14:e0008163.

37. Kamgang B, Vazeille M, Tedjou AN, Wilson-Bahun TA, Yougang AP, Mousson $L$, et al. Risk of dengue in Central Africa: vector competence studies with Aedes aegypti and Aedes albopictus (Diptera: Culicidae) populations and dengue 2 virus. PLoS NegI Trop Dis. 2019;13:e0007985.

38. Bitsindou $\mathrm{P}$, Bantsimba-Ndziona M, Lenga A. Current distribution and bioecological characterizations of Aedes aegypti and Aedes albopictus in Brazzaville. Bull Soc Pathol Exot. 2018;111:301-8.

39. Kevin NH, Feng LJ. Urbanization and the risk of flooding in the Congo; case of the city of Brazzaville. AJER. 2015;4:48-53.

40. Edwards FW. Mosquitoes of the Ethiopian Region III-Culicine adults and pupae. London: British Museum (Natural History); 1941.

41. Jupp PG. Mosquitoes of southern Africa: culicinae and toxorhynchitinae. Johannesburg: Ekogilde Publishers; 1996.

42. WHO. Technical guide for a system of yellow fever surveillance. Geneva: World Health Organisation; 1971.

43. Organisation PAHO. Dengue and dengue hemorrhagic fever in the Americas: guidelines for prevention and control. Washington DC: Pan American Health Organisation; 1994.

44. Hammond SN, Gordon AL, Lugo EDC, Moreno G, Kuan GM, López MM, et al. Characterization of Aedes aegypti (Diptera: Culcidae) production sites in urban Nicaragua. J Med Entomol. 2007;44:851-60.

45. R Core Development Team. R: a language and environment for statistical computing. Vienna: R Foundation for Statistical Computing; 2018.

46. Burnham KP, Anderson DR. Practical use of the information-theoretic approach. Model selection and inference. New York: Springer; 1998. p. 75-117.

47. QGIS Development Team. QGIS 3.8.1 Geographic Information System. Open source geospatial foundation project; 2019. https://www.npack d.org/p/agis/3.8.1. Accessed 2 May 2012.

48. Adam JP, Melchio MF, Lancien J, Le Pont F. Répartition des vecteurs potentiels de fièvre jaune en République Populaire du Congo. Brazzaville: ORSTOM; 1973

49. Reiskind M, Lounibos L. Spatial and temporal patterns of abundance of Aedes aegypti L. (Stegomyia aegypti) and Aedes albopictus (Skuse) [Stegomyia albopictus (Skuse)] in southern Florida. Med Vet Entomol. 2013:27:421-9.

50. Lounibos L, Suárez S, Menéndez Z, Nishimura N, Escher R, O Connell $S$, et al. Does temperature affect the outcome of larval competition between Aedes aegypti and Aedes albopictus? J Vector Ecol. 2002;27:86-95.

51. Kittayapong P, Strickman D. Distribution of container-inhabiting Aedes larvae (Diptera: Culicidae) at a dengue focus in Thailand. J Med Entomol. 1993:30:601-6

52. Ohashi K, Takano M, Xaypangna T, Nishiyama T. Difference in larval habitat size between Aedes aegypti and Aedes albopictus in a dengue endemic village, Lao People's Democratic Republic. Southeast Asian J Trop Med Public Health. 2018;49:761-9.

53. Reiter P. Aedes albopictus and the world trade in used tires, 1988-1995: the shape of things to come? J Am Mosq Control Assoc. 1998;14:83-94. 
54. Barrera R, Amador M, Clark GG. Ecological factors influencing Aedes aegypti (Diptera: Culicidae) productivity in artificial containers in Salinas, Puerto Rico. J Med Entomol. 2006;43:484-92.

55. Cox J, Grillet ME, Ramos OM, Amador M, Barrera R. Habitat segregation of dengue vectors along an urban environmental gradient. Am J Trop Med Hyg. 2007;76:820-6

56. Zahiri N, Rau ME. Oviposition attraction and repellency of Aedes aegypti (Diptera: Culicidae) to waters from conspecific larvae subjected to crowding, confinement, starvation, or infection. J Med Entomol. 1998:35:782-7.

57. Parker AT, Gardner AM, Perez M, Allan BF, Muturi EJ. Container size alters the outcome of interspecific competition between Aedes aegypti (Diptera: (ulicidae) and Aedes albopictus. J Med Entomol. 2019;56:708-15.

58. Rey JR, Nishimura N, Wagner B, Braks MA, O'Connell SM, Lounibos LP. Habitat segregation of mosquito arbovirus vectors in south Florida. J Med Entomol. 2006;43:1134-41.
59. Lounibos LP. Invasions by insect vectors of human disease. Annu Rev Entomol. 2002:47:233-66.

60. Juliano SA, Philip Lounibos L. Ecology of invasive mosquitoes: effects on resident species and on human health. Ecol Lett. 2005;8:558-74.

61. Bowman LR, Runge-Ranzinger S, McCall PJ. Assessing the relationship between vector indexes and dengue transmission: a systematic review of the evidence. PLoS Negl Trop Dis. 2014;8:e2848.

62. Focks DA, Chadee DD. Pupal survey: an epidemiologically significant surveillance method for Aedes aegypti: an example using data from Trinidad. Am J Trop Med Hyg. 1997;56:159-67.

\section{Publisher's Note}

Springer Nature remains neutral with regard to jurisdictional claims in published maps and institutional affiliations.
Ready to submit your research? Choose BMC and benefit from:

- fast, convenient online submission

- thorough peer review by experienced researchers in your field

- rapid publication on acceptance

- support for research data, including large and complex data types

- gold Open Access which fosters wider collaboration and increased citations

- maximum visibility for your research: over $100 \mathrm{M}$ website views per year

At BMC, research is always in progress.

Learn more biomedcentral.com/submissions 